\title{
Cumhuriyetin Illk Yıllarında Türk Basınında Suriye (1923-1927)
}

\section{Burhan Acar}

\section{Özet}

Dört asır boyunca Osmanlı hâkimiyeti altında bulunan Arap coğrafyasının, I. Dünya Savaşı'nda İngiliz ve Fransız kuvvetleri tarafından işgal edilmesiyle birlikte Türk-Arap birlikteliği de sona ermiş oldu. Ancak bu birlikteliği son dönem Türk-Arap ilişkileri açısından asıl parçalayan husus, Hicaz Emiri Şerif Hüseyin'in Osmanlı yönetimine karşı gerçekleştirdiği isyandır. Şerif Hüseyin'in gerçekleştirdiği isyan Türk ve Arap devletlerinin ulus-devlet süreçlerinde önemli bir argüman olarak işlenmiş, "Büyük Arap isyanı" ve "Arap ihaneti" olarak tarafların tarihlerinde önemli yer tutmuştur. Mezkur isyanın tüm Araplara mal edilerek, yüzyıllarca süren Osmanlı hakimiyetine son veren isyan olarak ele alınması Türk-Arap ilişkilerinde bir travma oluşturmuştur.

Son dönemde yapılan çalışmalarla söz konusu bakış açısı değişmeye başlamıştır. Yeni yapılan çalışmalarla Türk-Arap ilişkilerinin yalnız Şerif Hüseyin'in isyanı üzerinden değil, diğer aktörler üzerinden de okunması gerektiğinin önemi ortaya çıkmıştır. Bu aktörlerden biri de Arap halkıdır. Bu makalede, Osmanlı hâkimiyetinin Arap topraklarında başladığı ilk bölge olan ve yine Arap milliyetçiliğinin ilk nüvelerinin ortaya çıktığı yer olan Suriye ve Suriye halkına dair gelişmelerin Cumhuriyetin ilk yıllarında Türk basınına nasıl yansıdığını görmek amaçlanmıştır. Hakimiyet-i Milliye, ikdam ve Vakit gazetelerinde 1923-1927 yıllarını kapsayan süreçte yapılan taramalar bize hem Türk kamuoyunun Araplara bakış açısını bir parça sunarken hem de Arapların Türkiye'ye olan bakış açısını Türk basınının gözünden görme imkanını sunmaktadır.

Anahtar Kelimeler: Suriye, Türkiye, Arap İsyanı, Türk Basını

\section{Syria in the Turkish Press in Early Years of the Turkish Republic (1923-} 1927)

\section{Abstract}

With the occupation of the Arab lands, in which were under Ottoman rule for four centuries, in the First World War by the British forces, the prolonged Turkish-Arab co-existence has come to an end. However, the fact that this union breaks down in terms of the recent Turkish-Arab relations is the

\footnotetext{
* Yüksek Lisans Öğrencisi, Sakarya Üniversitesi, Sosyal Bilimler Enstitüsü, Tarih ABD, Türkiye Cumhuriyeti Tarihi Bilim Dalı, acaraburhan@gmail.com. (Makale Gönderim Tarihi: 09.02.2018; Makale Kabul Tarihi: 12.04.2018) (ORCID ID: 0000-0001-71132279)
}

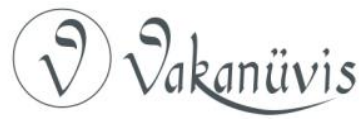


rebellion that the Amir of Hejaz Sharif Hussein made against the Ottoman government. The rebellion that Sharif Hussein made was an important argument in making the nation-state processes of the Turkish and Arab states and played an important role in the history of these nation-states as "Great Arab Revolt" or "Arab Betrayal". Appropriating the rebellion to all the Arabs, which is stated as a rebellion that ended the centuries-old Ottoman rule, created a trauma in Turkish-Arab relations.

However, with the recent studies, the point of this view has begun to change. With the new studies, it is important that the recent Turkish-Arab relations should be read not only through the rebellion of Sharif Hussein but also through behaviors of the other actors. One of these actors is the Arab people. In this article, it is aimed to see that developments of the Syrian people and in the Syria, in which the first region of Ottoman rule in the Arab lands, and where the first nucleus of Arab nationalism emerged, reflected in media in the early years of Turkish Republic. In this context, make screening of Hakimiyet-i Milliye, ikdam and Vakit newspapers, the period covering the years 1923-1927, gives us a piece of Turkish public perspective on the Arabs, also gives the opportunity to see, through the eyes of Turk press, the Arabs perspective on Turkey.

Keywords: Syria, Turkey, the Arab Rebellion, Turkish Press

\section{Giriş}

Yavuz Sultan Selim'in Mercidabık Savaşında kazandığı zaferle birlikte Suriye topraklarında Osmanlı hakimiyeti başlamıştır. Bu zafer, Arap halklarının Osmanlı İmparatorluğu çatısı altında yaşayacakları dört yüz yıllık bir sürecin de başlangıcı olmuştur. 1516 yılından 1918 yılına kadar süren Osmanlı hakimiyeti dönemi, Arap-Türk birlikteliğinin hilafet çatısı altında sağlandığı bir dönemdir. Ancak Avrupalı emperyalist devletlerin bölgeye olan ilgilerinin artmasıyla birlikte, Osmanlı Arap coğrafyası sancılı bir dönem içine girmiştir. Bilhassa Fransız İtilalinden doğan modern milliyetçilik düşüncesinin, batılı devletler tarafından bölge halkına ihraç edilmesiyle birlikte önemli kırımaların yaşandığı bir süreç de başlamıştır. Arap milliyetçiliğinin ortaya çıktığı ilk bölge Suriye'dir. Arap milliyetçiliğinin ilk olarak Suriye'de görülmesindeki en önemli etken yabancı okullardır. Batılı devletler Suriye'de açtıkları okullarla, milliyetçilik düşüncesini Hristiyan 
Araplar üzerinden bölgeye aktarabilmişlerdir. ${ }^{1}$ Hristiyan Arap entelektüel kesimde ortaya çıkan milliyetçilik düşüncesi zamanla Batılılaşmış Müslüman Arap aydınları arasında da yayılmış, ancak halk nezdinde önemli bir etkiye sahip olamamıştır. ${ }^{2}$ Sultan II. Abdülhamit devrinde uygulanan politikalarla birlikte Arap milliyetçiliği Türk-Arap ilişkilerini etkileyecek bir boyuta ulaşamamıştır ${ }^{3}$. Milliyetçilik düşüncesinin Türk-Arap ilişkilerini olumsuz etkilediği asıl dönem I. Dünya Savaşı́nın ardından ortaya çıkan ulus-devletleşme sürecidir. Bilhassa I. Dünya Savaşı sırasında İngilizlerin desteğiyle Hicaz Emiri Şerif Hüseyin tarafından başlatılan isyan, savaşın ardından ortaya çıkan Türk ve Arap ulus-devletleri döneminde önemli bir kırılma görevi görmüştür. Şerif Hüseyin, uluslaşma sürecinde Arap milliyetçiliğinin temel argümanı haline getirilmiş ve Arap milliyetçileri tarafından sömürge dönemi ${ }^{4}$ olarak görülen Osmanlı hakimiyetini sona erdiren ulusal kahraman olarak kabul edilmiştir. Bu sebepledir ki ulusdevletlerin ve ulus-devlet destekli tarihçilerin elinde, Şerif Hüseyin'in gerçekleştirmiş olduğu isyan "Büyük Arap İsyanı" olarak kabul görmüştür. Şerif Hüseyin'in I. Dünya Savaşı sırasında gerçekleştirdiği isyanın "Büyük Arap İsyanı" olarak görülmesinde ilk dönem batılı çalışmaların etkisi önemlidir. Bu çalışmalardan en önemlisi ise George Antonius'un "Arab Awakening" adlı eseridir. Illk dönem Arap tarihi çalışmaları söz konusu eserin etkisinde kalmış ve Şerif Hüseyin'in isyanı zamanla tüm Arap halkına mal edilecek bir şekilde işlenmiştir.

\footnotetext{
${ }^{1}$ Derviş Kılınçkaya, Osmanlı Yönetimindeki Topraklarda Arap Milliyetçiliğinin Doğuşu ve Suriye, 2. Baskı, Ankara, 2008, s.12.

${ }^{2}$ William Cleveland, Modern Ortadoğu Tarihi, 1.Baskı, İstanbul, 2008, s.160-161.

${ }^{3}$ Zekeriya Kurşun, Türk-Arap ilişskileri, 1.Baskı, İstanbul, 1992, s. 33.

4 "Osmanlı sömürge dönemi" kavramıyla ilgili olarak, Suriye'de Eğitim Bakanlığı tarafından basılan dokuzuncu sınıf ders kitabında (Tarihü'l-Arap Hadis ve'l Muasır, 2005:10-15) "sömürü" ve "işgal" gibi ifadeler kullanılmıştır. Söz konusu kitabın "Osmanlı Devleti'nin Arap Topraklarını İşgali" başlıkı kısmında, Osmanlı hakimiyetinde Arap dünyası "Tarım, ticaret ve sanayide geri kalmıştır." ve "ittihatçı Türkler Arap beldelerinde Türkleştirme politikası uygulamışlardır." gibi ifadeler yer almıştır. Kaynak: Talha Çiçek, Şerif Hüseyin Isyanının Türk ve Arap kimlik Inşa Süreçlerindeki Etkisinin Analizi, Yayınlanmamış Yüksek Lisans Tezi, Sakarya 2007, s.110-111.; Ayrıca bkz.; Jane Hathaway, Osmanlı Hakimiyetinde Arap Toprakları, 1. Baskı, İstanbul, 2016, s.5, s.13; Kemal Karpat, Ortadoğu'da Millet, Milliyet, Milliyetçilik, 1. Baskı, 2011, s.85, s.257.
}

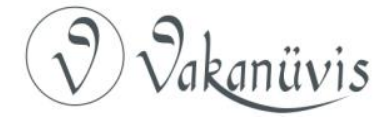


Şerif Hüseyin'in gerçekleştirmiş olduğu isyan, Türkiye Cumhuriyeti devletinin ulus-devlet sürecinde ise "Arap ihaneti" olarak işlenmiştir. "Arap ihaneti" Türk ulus kimliğinin inşa sürecinde önemli bir argüman olarak kullanılmıştır. ${ }^{5}$ Hilafetin kaldırıması, Arap harflerinin terk edilmesi gibi inkılaplarda ve İslam dünyasından uzaklaşma sürecinde "Arap ihaneti" bir etken olarak sunulmuştur. ${ }^{6}$ Kimi Türk aydınları ve tarihçileri yaşanan süreçte milliyetçilik etkisini öne çıkarmışlar ve isyanın Osmanlı toplumunda yer tutan ümmetçilik düşüncesinin iflasını gösteren bir etken olduğuna dair çalışmalar yapmışlardır. Bu sebepledir ki I. Dünya Savaşı'nda gerçekleşen isyan, bütün Araplara mal edilmiş ve İslam öncesi Türk tarihinin ön plana çıkartılmasında etkili unsurlardan biri olmuştur. İsyan, İslam dininin birleştirdiği iki toplum için bir travma görevi görmüştür. Şerif Hüseyin'in gerçekleştirmiş olduğu isyanın, Arap ihaneti olarak işlenmesi Türk toplumunun Araplara olan bakışını olumsuz etkilemiştir. Bunun en önemli sonucu iki millet için güçlü bir bağ olan dinin etkisinin zayıflaması ve (kavimsel) Türklüğün ön plana çıkmasıdır. ${ }^{7}$ Arap devletlerinde olduğu gibi Türkiye'de de ulus-devlet destekli tarihçilerin çalışmalarıyla Şerif Hüseyin'in isyanı "Büyük Arap İsyanı" olarak ders kitaplarındaki yerini almıştır. ${ }^{8}$

Ancak son dönemde yapılan çalışmalarla birlikte var ola gelen tarih okuması değişmektedir. ${ }^{9}$ Yeni yapılan çalışmalarla Şerif Hüseyin isyanının, Arap milliyetçiliği yönü tartışmalı hale gelmiş ve isyanın tüm Arap milletine mal edilemeyeceği görülmüştür. ${ }^{10}$ I. Dünya Savaşı'na Cemal Paşa'nın kurmay başkanı olarak katılan Ali Fuat Erden, dönemin tanığı olarak isyanı "Hicaz isyanı" olarak değerlendirmiş ve bir Arap isyanı olmadığını ifade etmiştir:

"Arap ihtilali teşebbüsü tohum iken yok edildi. 1915 yılındaki bu ihtilal teşebbüsünden sonra, savaş süresince Suriye ve

\footnotetext{
${ }^{5}$ Talha Çiçek, Erken Cumhuriyet Dönemi Ders kitapları Çerçevesinde Türk Ulus Kimliği Inşası ve Arap Ihaneti, Disiplinler Arası Çalışmalar Dergisi, cilt: 17, sayı: 32, 2012, s. 169-188.

${ }^{6}$ François Georgen, Osmanlı-Türk Modernleşmesi, İstanbul, 2016, s. 10.

${ }^{7}$ Karpat, a.g.e., s. 42.

${ }^{8}$ Çiçek, a.g.m., s. 169-188.

${ }^{9}$ Ernest Dawn, Osmanlıcılıktan Arapçılığa, İstanbul, 1998, s. 8-9.

${ }^{10}$ Dawn, a.g.e., s. 8.
}

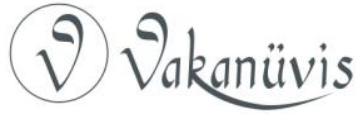


Filistin'de asayişi bozacak hiçbir hareket olmadı. Hicaz isyanı Arap isyanı değildi. Mekke Emiri Şerif Hüseyin'in isyanıydı ve Ingiliz ajanları tarafından Ingiliz altını, Ingiliz buğday ve pirinci ile elde edilen urbanın (Çöl Araplarının) yardımıydı. ${ }^{11}$

Tarihçi William Cleveland ise Arap halkının büyük kısmının Osmanlı taraftarı olduğunu şu şekilde ifade etmiştir:

"1908'den 1928'e kadar imparatorluğun Arap halkının ezici çoğunluğunun Osmanlıcılığ desteklemiş olduklarını anlamak çok önemlidir. Halkın Osmanlı devletine sadakat alışkanlığı ve halifesultanı islam ümmetinin koruyucusu olarak görmesi, bu desteğin başlıca unsurlarındandır." ${ }^{\prime 12}$

İsyanın ilk dönem ki sınırlı etkisine rağmen ulus-devlet sürecinde Arap milliyetçiliği, isyanın etrafında şekillenmiştir. I. Dünya Savaşı'nın ardından ortaya çıkan Arap devletleri tarafından da Osmanlı hakimiyet dönemi bir nevi sömürü dönemi olarak görülmüştür. Bu nedenle Şerif Hüseyin'in gerçekleştirmiş olduğu isyan, sömürü düzenine son veren "Büyük Arap Devrimi" ve "Arapların Uyanışı" olarak işlenmiştir. ${ }^{13}$ İsyan bazı Türk milliyetçi/ulusalcı aydınlar tarafından da "Arap ihaneti" olarak kabul edilmiştir. Bu durum ise Türk-Arap ilişkilerine olumsuz bir şekilde yansımıştır.

Günümüzde Türk-Arap ilişkilerinin "Arap İsyanı” üzerinden değerlendirilmesi büyük sorunları da beraberinde getirmiştir. Bu sorunları aşmanın en önemli yolu ise diğer unsurların da dikkate alınmasıdır. Bu unsurlardan en önemlisi Arap ve Türk halklarıdır. Dönemin tanıklarının ifadeleri Arap milliyetçiliğinin ve Osmanlı karşıtlı̆ının tüm Arap halkı tarafından benimsenmediğini göstermektedir. Benzer şekilde Arapların hain olduğu düşüncesinin de bütün Türkiye halkı tarafından benimsenmediği görülmektedir. Irak ve Suriye halklarının Türkiye'ye olan bakış açısını göstermesi bakımından önemli bir ifade ise Mustafa Kemal Atatürk'e aittir. Dönemin Arap halkının, Türkiye'ye olan olumlu bakış açısını teyit eden Mustafa Kemal

\footnotetext{
${ }^{11}$ Ali Fuat Erden, Birinci Dünya Savaşı'nda Suriye Hatıraları, (haz. Alpay Kabacalı) İstanbul, 2006, s.68-69.

${ }^{12}$ Cleveland, a.g.e., s. 160-161.

${ }^{13}$ Ayrıntılı kaynak için bkz. 4'nolu dipnot.
}

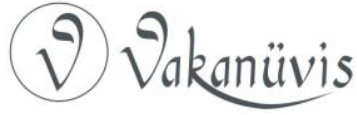


Atatürk, 24 Nisan 1920'de Meclis'te yaptığı konuşmada, şu ifadeleri kullanmıştır:

"...ve bugün dahi gerek zahiriyesi ne olursa olsun gerek Iraklıların ve gerek Suriyelilerin bu iki mıntıkadaki dindaşlarımızın kalpleri bizimle beraberdir. ${ }^{14}$

Bu ifadelerde Suriye ve Irak Arap halkının Türkiye'ye olan kalbi bağ|ılığı, modern Türkiye'nin kurucusu tarafından teyit edilmektedir.

Osmanlı sonrası Arap milletinin Türkiye'ye olan bakış açısını ve Türkiye'de Araplara olan bakış açısını görmenin önemli bir aracı da basındır. Dönemin halkının bakış açısını bir parça da olsa yansıtması bakımından basının önemli bir rolü bulunmaktadır. Türkiye Cumhuriyeti'nin ilk yıllarında Türk basınının Araplara dair bakış açısı, Suriye'de kurulan manda sistemine yaklaşımı nasıldı? Bu sorunun cevabı, bugün kritik bir süreci yaşayan Türkiye-Suriye ilişkilerinin kökenlerinin görülmesi açısından önemlidir. Elde edilen veriler bize savaşın ardından Osmanlı hakimiyetinden çıkan Suriye bölgesine dair Türk basınının ilgisini ve bakış açısını sunmaktadır. Ayrıca Türk basınına yansıyan kimi haberler, Suriye halkının Türkiye'ye olan bakış açısını göstermektedir. Bu veriler Cumhuriyetin ilk yıllarında Türk-Arap ilişkilerinin anlaşılması hususunda önem arz etmektedir.

\section{Fransız İşgalindeki Suriye'de İsyanlar}

Suriye'deki Osmanlı hakimiyetinin son bulması, bölgenin kaderini de değiştirmiştir. I. Dünya Savaşı'nda İngiliz hakimiyetindeki Mısır üzerine gerçekleştirilen Kanal Harekâtının başarısız olmasıyla birlikte karşı taarruza geçen İngilizler, Osmanlı kuvvetlerini geriletmiş ve Suriye eyaletlerini ele geçirmişlerdir. Bu dönemde Hicaz'da, İngilizlerin desteği ve vaatleriyle isyan etmiş olan Şerif Hüseyin ise bölgedeki Osmanlı kuvvetlerine karşı saldırılara başlamıştır. İngiliz kuvvetleri karşısında yenilgiye uğramış olan Osmanlı kuvvetlerinin Şam'ı boşaltması üzerine, Şerif Hüseyin'in oğlu Faysal'ın komutasındaki isyancı gruplar yine İngilizlerin izniyle Şam'a girmiştir. ${ }^{15}$ Ancak Faysal'ın bilmediği gerçek, İngilizlerin Faysal'ın babasına vaatlerde bulunurken

\footnotetext{
${ }^{14}$ TBMM GCZ, 24 Nisan 1336 (1920), Ankara: İş Bankası Kültür Yayınları, 1985, C.1, Devre 1, İçtima 1, İn'ikat 2, 24.4.1336.

${ }^{15}$ David Fromkin, Barışa Son Veren Savaş, İstanbul, 2016, s. 296
}

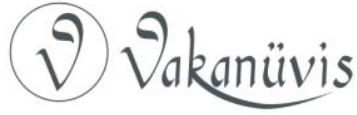


Fransızlar ile Skyes-Picot Antlaşmasını imzaladığıdır. ${ }^{16}$ Yapılan antlaşmalara göre Suriye toprakları Fransa'ya bırakılmıştır. Şam'a giren Faysal, Suriye'nin genelinde hakimiyetini sağlamak amacıyla Beyrut'a kuvvetlerini gönderdiğinde bölgenin hakimi olarak karşısında Fransızları bulmuştur. Emir Faysal kısa sürede kendini Suriye Kral'ı olarak ilan etse de Fransız ordusu karşısında tahtını terk etmek zorunda kalmıştır.

Fransız ordusunun, Suriye'ye girmesiyle birlikte, 1920 yılından 1946 yılına kadar uzanacak sömürge yönetimi de başlamış oldu. Fransız yönetiminin Suriye'de inşa ettiği temel politika ise "Böl ve Yönet" politikasıdır. ${ }^{17}$ Sömürge yönetiminin ilk icraatı; Beyrut, Beka Vadisi, Trablusşam, Sayda ve Sur şehrini içine alan Beyrut devletinin varlığını 1920 Ağustosunda ilan etmesidir. Ardından geriye kalan Suriye toprakları Halep, Şam, Laskiye ve Cebel-i Dürzi olarak ayrı vali ve danışmanlarla birlikte dört ayrı yönetime bölünmüştür. ${ }^{18}$ Fransızların bir diğer argümanı ise Suriye toplumunu Nusayri, Dürzi ve Sünni farklılıkları ön plana çıkararak bölmesidir. Bu şekilde Suriye toplumu dinsel ve bölgesel olarak parçalı bir hale getirilmiş ve Fransız yönetiminin tahakküm gücü arttırılmıştır. Yine de Suriye Fransız idaresini kurmak kolay olmamış ve Fransız istilasının başladığı andan itibaren bir direniş de ortaya çıkmıştır. Bilhassa 1920'li yılların başında Anadolu'daki Kuva-yı Milliye hareketi ile Suriye direnişinin ortak faaliyetleri, Fransız yönetimini oldukça tedirgin etmiştir. ${ }^{19}$

Milli Mücadele döneminde Urfa ve Maraş şehirlerinde gerçekleşen mücadelede, Halep bölgesindeki direnişçilerin faaliyetleri Fransız yönetimini oldukça zor bir durumda bırakmıştır. Suriye'de gerçekleşen direniş bir süre sonra kontrol altına alınabilse de 1923 yılında, çatışmaların dönem dönem devam ettiği görülmektedir.

Türk basını, Türkiye Cumhuriyeti'nin ilk yıllarında Suriye'de yaşanan gelişmeleri takip etmiş ve vakaları gazete sütunlarına taşımıştır. 1923 yılında dikkat çeken isyanlardan biri Havran sancağının merkezi olan Dera'da çıkmıştır. İsyan, 12 Ekim 1923 tarihinde Hakimiyet-i Milliye'de

\footnotetext{
${ }^{16}$ Tayyar Arı, Orta Doğu, Bursa, 2008, s. 139

${ }^{17}$ Cleveland, a.g.e., s. 243

${ }^{18}$ Ömer Osman Umar, Suriye, Ankara, 2004, s. 455

${ }^{19}$ Umar, a.g.e., s. 466
}

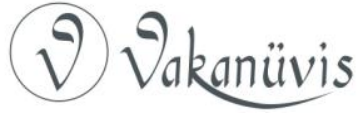


"Suriye Havadisleri" başlığıyla verilmiştir. Ahenk gazetesinden edinilen bilgilere göre, isyan eden Havran ahalisi on iki bin kişiden oluşan silahlı birliklerle Dera şehrini ele geçirmiştir. İsyancı gruplar ilk olarak Hükümet konağını ele geçirip memurları kovmuşlar ve Fransızlarla işbirliği içinde olanların mallarına el koymuşlardır: "İ̧̧gal münasebetiyle Müslümanlara hıyanet edenlerin bütün emvalini müsadere ve kendilerini Fransa'ya gidin diye tard eylediler." İsyancıların Dera'ya hakim olduğunu gören Fransızlar bölgedeki olayları yatıştırmak için bir nasihat heyetini isyancılara gönderseler de istediklerini elde edememişlerdir. Büyük bir tepkiyle karşılanan heyetin başkanı Şam eşrafından Abdurrahman Paşa, isyancılarla konuşmaya çalıştığında şu cevabı almıştır:

"Din düşmanlarıla el ele vererek bizim gibi hür yaşamış insanları Türk kardeşlerimizden ayırdınız. Şimdi de düşmana arz-ı dahalet edelim diye bizi iğfale geliyorsunuz. Bunu bildiğimiz için işte sizi silahlarla istikbale çıktık nankörlüğünüzün cezasını tayin edeceğiz."

Bu cevabın ardından Abdurrahman Paşa feci bir şekilde isyancıların elinde can vermiştir. ${ }^{20}$ İsyancı Havran ahalisinin Abdurrahman Paşa'ya ifade ettikleri oldukça dikkat çekicidir. Bu ifadelere göre Havran ahalisi Türkleri kardeş olarak görmekte ve Fransız güçleriyle işbirliği yapan, Şam eşrafından Abdurrahman Paşa'yı katledecek kadar öfkeli bulunmaktaydı.

1923 yılında gerçekleşen isyanlardan biri de "Suriye ve Fransa" başlı̆ııla 18 Temmuz 1923 tarihinde verilmiştir. Suriye'nin her tarafında Fransızlara karşı şiddetli çatışmalar içine giren isyancı gruplar için Hakimiyet-i Milliye "Mücahitler" ifadesini kullanmıştır. İsyancı gruplar sık sık yolculuk etmekte olan Fransız müfrezelerine saldırılarda bulunmaktadırlar. Aktarılan saldırılardan ilki "Cebel-i Zaviye mücahitleri" tarafından gerçekleştirilmiş ve üç saat süren çatışmaların sonunda Fransızlar biri zabit olmak üzere on altı ölü ve yirmi yaralı vermişlerdir. Fransızlara karşı gerçekleşen bir diğer saldırı ise İdlib'den Halep'e doğru yola çıkan Fransız postasına karşı gerçekleştirilmiştir. Haberde dikkat çeken asıl saldırı ise Halep'te gerçekleşmiştir.

${ }^{20}$ Suriye Havadisleri, Hakimiyet-i Milliye, 12 Ekim 1923.

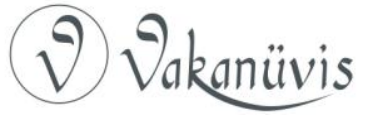


Haziran'ın 25. Gecesi gerçekleşmiş olan saldırıda "Mücahitler" Halep Karakolu'na baskın düzenlenmiş, üç zabit ve beş nefer ele geçirilmiştir. Mücahitler bu sırada ele geçirdikleri kadınları serbest bırakmışlar ve şu dikkat çekici açıklamayı yapmışlardır:

"Gidiniz bizim kadın ve .... işimiz yoktur, memleketimizi terk ettiğiniz gün Erkekleriniz de hayatlarını kurtarmış olacaklardır. Aksi takdirde ya biz veya siz neticeye kadar çatışacağız ve biz Halepliler tamamen mahvolmadıkça bu yerler size mal olmaz."

$\mathrm{Bu}$ ifadelerde Halepli direnişçilerin kararlılığı görülmektedir. Saldırılar üzerine Fransızlar, 28 Haziran'da mücahit grubuna karşı taarruzda bulundularsa da, Mücahitler hiçbir kayıp vermezken Fransızlardan iki ölü ve beş yaralı olduğu bildirilmiştir. ${ }^{21} 1923$ yılından gerçekleşen isyanlara karşı Fransız idaresi birtakım önlemler almak zorunda kalmış ve aldığı önlemler sayesinde bir nebze isyanları kontrol altına alabilmiştir. Bu önlemlerden bir tanesi de 26 Eylül 1923 tarihli Hakimiyet-i Milliye'de "Suriye Haberleri" başlı̆ııla yer almıştır. "Halep'te içten içe kaynayan bazı milli cereyanları bastırmak için Fransız Askeri Divan-ı Harbi şiddetli kararlar vermektedir." ifadeleriyle anlatılan vakıada, Divan-ı Harbin almış olduğu şiddetli kararlar habere yansımıştır. Gazetenin bilhassa dikkat çektiği ceza ise müsaderedir. Müsadere Divan-ı Harbin en çok uyguladığı ceza olarak haberde yer almış ve müsadere cezasıyla isyancılar yıldırılmak istenmiştir. ${ }^{22}$

Şiddetli çatışmaların yaşandığı 1923 yııının ardından alınan önlemlerle birlikte 1924 yılı daha sakin bir yıl olarak geçse de, Fransızlar için asıl tehdit 1925 yııının son döneminde başlamıştır. Suriye direnişinin en güçlü olduğu dönem olan 1925 ve 1926 tarihleri, Fransız idaresini oldukça zor bir duruma sokmuştur. Cebel-i Dürzi merkezli ortaya çıkan isyan Şam ve Halep'teki milliyetçilerin desteğiyle kısa sürede büyüyerek tüm Suriye'yi sarmıştır. İsyanın kıvılcımını çakan vaka ise, Cebel-i Dürzi devletinde Fransız yönetiminin, Atraş ailesinin nüfuzunu kırma ve Dürzilerin siyasal ilişkilerini reformlar adı altında düzenleme çabasıdır. ${ }^{23}$ Fransız idaresinin baskıcı yönetimi karşısında Dürziler tepki gösterip bir takım haklar talep etseler de bu taleplerin

\footnotetext{
${ }^{21}$ Suriye ve Fransa, Hakimiyet-i Milliye, 18 Temmuz 1923.

${ }^{22}$ Suriye Haberleri, Hakimiyet-i Milliye, 26 Eylül 1923.

${ }^{23}$ Cleveland, a.g.e., s. 248.
}

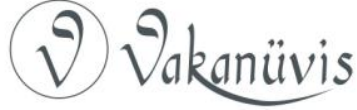


Fransızlar tarafından reddedilmesi üzerine, Dürzi lider Sultan Paşa elAtraş'ın önderliğinde ilk saldırılar başlamıştır. İsyanın ilk döneminde elAtraş'ın önderliğindeki isyancılar tarafından Salhad'da ki Fransız sevkiyat merkezi yok edilmiştir. İsyancı gruplar hızlı bir şekilde teşkilatlanarak Sultan el- Atraş'ı isyanın genel komutanı olarak seçmiştir. İsyana karşı harekete geçen Fransız kuvvetleri ise üstün silah ve teçhizata rağmen direnişçilerle baş edememiş ve şehirlere karşı ağır bombardıman saldırıları gerçekleştirmiştir. Bu saldırılardan en bilineni ise 1.400 kadar Suriyelinin hayatını kaybettiği 18 Ekim 1925 tarihli 48 saat süren bombardımandır. ${ }^{24}$

Söz konusu dönem Türk basınında ilgiyle takip edilmiş ve direniş ile Fransız idaresi arasındaki çatışmalar sık sık basında yer bulmuştur. Suriye'deki direnişin büyümesine paralel olarak Türk basınında yer bulmaya başlayan haberler ilk olarak Dürzi ayaklanmasına odaklanmıştır. Vakit'in 20 ve 21 Ağustos 1925 tarihli haberlerinde, Dürzi isyanının büyüdüğü ve çatışmaların devam ettiği aktarılmıştır. ${ }^{25}$ İsyanın ayrıntılarına dair 28 Ağustos 1925 tarihli haberde ise Vakit iki iddiayı okuyucularına sunmuştur. "Şam Tehlikede mi?" başlığıyla verilen haberde ilk iddia Vakit gazetesinin hususi muhabirine aittir. Bu iddiaya göre Dürziler şiddetli çatışmaların ardından Şam'ı istila etmişlerdi: "Alınan haberlere nazaran Dürziler Şam'ı işgal etmişlerdir. Fransızlar dört bin zayiat vererek çekilmişlerdir. Mamafih bu haber başka taraflardan teyit edilemediği için kayd-ı intiyatla telakkisi lazımdır." Haberdeki ikinci iddia ise Anadolu Ajansı'na aittir: "Erbab-ı kıyamın 24 Ağustosta Şam üzerine icra ettikleri akın esnasında mühim zayiata uğradıkları teyit olunuyor." Şam'a karşı isyancıların saldırıları teyit edilse de Şam'ın durumu hakkından net bilgi bulunmamaktadır. ${ }^{26}$ Şam'ın duruma dair haber ise 31 Ağustos tarihinde Vakit'te karşımıza çıkmıştır. "Dürzi İsyanı Hangi Safhada Bulunuyor" başlığıyla verilen haberde Şam'ın henüz düşmediği ancak düşeceği iddia edilmektedir. Ingiliz kaynaklarından alınan bilgiye göre Fransızlar isyan karşısında zor

${ }^{24}$ Cleveland, a.g.e., s. 248

${ }^{25}$ Dürzi İsyanı, Vakit, 20 Ağustos 1925.

${ }^{26}$ Şam Tehlikede mi?, Vakit 28 Ağustos 1925.

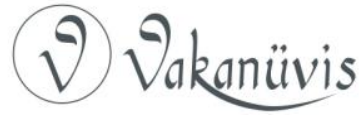


bir durumda bulunmaktadırlar. Fransızlar ise bu iddiaları reddedip endişeye gerek olmadığını söylemektedirler. ${ }^{27}$

Dürzi ayaklanmalarının Vakit gazetesine yoğun yansıdığı Eylül ayında ilk dikkat çeken haber ise 3 Eylül tarihinde karşımıza çıkmaktadır. "Fransızlar Zulüm Ektiler, İsyan Biçtiler" başlığıyla verilen haberde Dürzi ayaklanmasının sebepleri tahlil edilmeye çalışılmıştır. Habere göre Suriye'de manda yönetiminin başlamasıyla birlikte, Fransızlar Cebel-i Dürzi'de ayrı bir yönetim tesis etmişlerdir. Ancak bu hükümet Dürzi halka karşı baskıcı bir tutum takınmış ve Dürzileri Fransızlaştırma politikasını gütmüşlerdir: "Dürzileri Fransızlaştırmak için bütün şiddet ve mezalimini Dürzilere tatbik etmişlerdi." Cebel-i Dürzi yönetimi tarafından Dürzi liderlerin de aşağılanmaları üzerine, Dürziler Fransız yönetiminden idarenin değiştirilmesi talebinde bulunmuşlardır. Ancak bu istek reddedilmiştir. Bunun üzerine Dürziler tekrar bir talepte bulunsalar da bu istekleri de reddedilmiştir. Bu sebeple Dürziler bölgelerinde toplanmaya başlamıştır. Fransız yönetimi bir askeri kuvveti Dürzilerin toplandığı bölgelere göndermiştir. Askeri kuvvetin başındaki teğmenin Dürzilere karşı zorba tavırları olayları büyütmüştür: "Bu mülazımın elindeki kırbaçla önüne geleni dövmeye başlaması üzerine Dürzilerden biri mülazımın üzerine silah istimal etti. Esas vaka buradan çıkıyor." Bu vakanın ardından Dürziler Fransızlara karşı saldırılara başlamışlardır: "Dürziler toplanarak Suveyde'yi muhasara ettiler ve önlerine gelen Fransızları öldürmeye başladılar." İsyanın büyümesi üzerine Fransızlar askeri birliklerini bölgeye sevk etmeye başlamışlar: "8 Ağustos 1925 Fransızlar (Fransız, mağribi lejyon, Çerkes ve Kürtlerden) müteşekkil 4300 kişilik bir kuvvet gönderdiler." Habere göre harekete geçen Fransı kuvvetleri Şam civarında istirahat ederken, 800 kişilik Dürzi ekibi saldırıya geçti ve Fransız kuvvetlerini kılıçtan geçirerek top ve mitralyöz gibi ağır mühimmatı ele geçirdi. ${ }^{28}$ Dürzi kuvvetlerin gösterdikleri bu başarı isyanın etkisinin ilk işareti olarak karşımıza çıkmaktadır. Dürzi kuvvetlerin bir başka askeri başarısı ise Suveyde mevkini ele geçirmeleridir. "Dürziler Suvey'e Mevkine Girdiler" başlığıyla verilen 17 Eylül tarihli habere göre, Suveyde ele geçirilmiş, Fransızlardan

\footnotetext{
${ }^{27}$ Dürzi İsyanı Hangi Safhada Bulunuyor, Vakit, 31 Ağustos 1925.

${ }^{28}$ Fransızlar Zulüm Ektiler, İsyan Biçtiler, Vakit, 3 Eylül 1925.
}

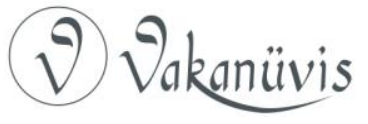


zabitleriyle birlikte dört yüz elli nefer esir alınmış ve iki büyük zırhlı otomobil ele geçirilmiştir. ${ }^{29}$

Dürzi isyanını sütunlarına yansıtmaya devam eden Vakit gazetesi, 20 Eylül 1925 tarihinde "Fransızlar ve Dürziler" başlığıyla isyana dair yeni gelişmeleri aktarmıştır. Habere göre Dürziler ile Fransızlar arasındaki "kanlı muharebeler" devam etmektedir. Fransızların amacının ise Dürzilerin yerine Ermenileri iskan etmek istedikleri iddia edilmiştir. Ancak isyanla ilgili önemli olan asıl gelişme, Şam ahalisinin isyana olan meylidir. Dürzi isyanının diğer kesimlere yansıması Fransızları güç durumda bırakacak bir süreci başlatacaktır. ${ }^{30}$ Fransızlar ise isyanı merkezinde bitirebilmek için Cebel-i Dürzi'yi kuşatma altına almışlardır. 24 Eylül tarihli Vakit'in haberine göre Fransız ordusunun bu muhasarasına karşııı Dürziler seferberlik gerçekleştirmekte ve "on altıdan altmış yaşına" herkesi silah altına almaktadır. ${ }^{31}$

Fransızların, Dürzi ayaklanmaları bastırma çabası yetersiz kalmış ve isyan kısa sürede Suriye'nin diğer şehirlerine yansımıştır. İsyanın yansıdığı ilk bölgelerden biri de Hama'dır. 8 Ekim 1925 tarihinde “ Suriye'de Karışıklık" başlığıyla verilen haberde Hama'da ahali ve bedevilerin resmi daireleri ele geçirmeye çalıştıkları ancak süvari birlikleri tarafından püskürtüldükleri ve çatışmalarda otuz kişinin öldürüldüğü aktarılmıştır. ${ }^{32} 8$ Ekim tarihli "Suriye'de Fransa" başlıklı bir başka haberde ise Fransız tebliğine yer verilmiştir. Tebliğe göre, Şam'ın batısında isyancı grupların toplanmakta olduğu aktarılmıştır. ${ }^{33}$

Şam'ın batısında toplanmakta olan isyancı gruplar Şam'a dahil olmuşlar ve Şam'ın kimi bölgelerini ele geçirmişlerdir: “Dürzi Kuvvetleri kısa bir müddet için Şam'ın bazı noktalarını işgale muvaffak oldular." ${ }^{34}$ Ancak Şam ahalisinin isyana katılmasıyla birlikte büyük "Şam Kıyamı" başlamış oldu. 22 Ekim tarihinde ise Dürzi ve ahaliden oluşan çetelerin Şam mahallerine gerçekleştirdikleri direniş "Şam Kıyamı" başlığıyla Hakimiyet-i Milliye gazetesinde yer buldu. İsyancılar Şam'ın güney

\footnotetext{
${ }^{29}$ Dürziler Suvey'e Mevkine Girdiler, Vakit, 17 Eylül 1925.

${ }^{30}$ Fransızlar ve Dürziler, Vakit, 20 Eylül 1925.

${ }^{31}$ Fransız Ordusu, Vakit, 24 Eylül 1925.

${ }^{32}$ Suriye'de Karışıklık, Hakimiyet-i Milliye, 8 Ekim 1925.

${ }^{33}$ Suriye'de Fransa, Hakimiyet-i Milliye, 8 Kasım 1925.

${ }^{34}$ Fransız Ordusu Ricat Etti mi?, Vakit, 21 Ekim 1925.
}

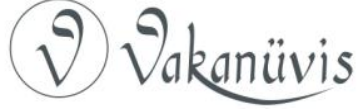


mahallerinde barikatlar kursalar da Fransız topçuları yoğun bir bombardıman gerçekleştirmiştir. Bombardımanın ardından Şam'ın varoşlarında ortaya çıkan isyan bastırımış ve şehrin ileri gelenleri binlerce tüfeği teslim etmek zorunda kalmışlardır. Haberde Şam'la birlikte isyanın başladığı yer olan Cebel-i Dürzi bölgesine dair bilgiler aktarılmıştır. Aktarılan bilgiye göre sık sık saldırılarda bulunan Dürzi kuvvetleri, Fransızlar tarafından dağlara sürülmüştür. ${ }^{35}$

28 Ekim tarihli haberde ise Hama'da ki gelişmeler "Suriye Vukuatı" başlığıyla verilmiştir. Haberde Hama şehrinin direnişçilerin eline nasıl geçtiği ve ardından Fransızların tekrar nasıl şehri geri aldıkları aktarılmıştır. İsyanın liderliğini altı senedir Fransız ordusunda görev yapan Şamlı Yüzbaşı Fevzi Efendi üstlenmiş ve kısa sürede Hama çevresinde güçlenen isyan Hama şehrini ele geçirmiştir. Yüzbaşı Fevzi ile ilgili bilgi şu şekildedir: "Altı seneden beri Fransız ordusunda müstahdem bulunan ve Hama etrafındaki eşkıya ve çetenin tardı ile muvazzaf olan Trablus Şamlı Yüzbaşı Fevzi Efendi maiyetindeki yüz kadar neferle ilanı isyan eylemiş." Yerel aşiretlerden destek bulan yüzbaşı kısa sürede Hama üzerine saldırıya geçip şehri ele geçirmiştir:

"Teşrin-i Evvelin onuncu günü gecesi Hama'ya hücum ve Hama'yı işgal ederek hapishanedeki mahpusları salıverdiler. Hapishanede üç yüz mahpus bulunuyordu. Bundan sonrada depolara hücum ederek içerisindeki mevcut eşya ile, bomba, makineli tüfenk esliha saireyi zapt ettiler."

Serbest bıraktıkları mahkumlara ve halka ele geçirdikleri silahları dağıtmışlardır. Telefon tellerini keserek hükümet dairelerini ele geçirmişler ve şehri yönetmeye başlamışlardır. Ancak çok geçmeden Fransız kuvvetleri savaş uçaklarının da desteğiyle harekete geçmişlerdir: "Fakat ertesi gün öğle vakti Fransız tayyareleriyle Fransız kuvvetleri yetiştiğinden bu gayrı muntazam kuvvetler Hama'yı terk etmeğe mecbur oldular." Şehri geri alan Fransız kuvvetleri isyanın bedelini halka ödetmeye çalışmıştır: "önlerine ilk rast gelene her muameleyi yapmaktan çekinmediler." Hama eşrafı ise tutuklanmıştır. Ayrıca Hama şehrinden ne kimsenin çıkabildiği ne de kimsenin şehre giremediği bildirilmiştir. Hama şehrini yoğun bombardıman altında tuttukları da haberde yer almıştır. Habere göre: "Halep İçinde

${ }^{35}$ Şam Kıyamı, Hakimiyet-i Milliye, 22 Ekim 1925.

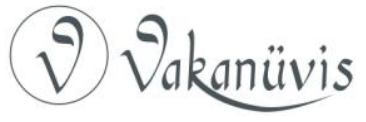


fevkalade endişe vardır. Halepliler korku ve endişe içindedirler. Halep'in bir saat haricinde katiyen emniyet yoktur." ${ }^{36}$

Fransız kuvvetleri kısa sürede Halep'teki isyanı bastırsa da bu dönemde Şam merkezli isyan büyümektedir. Şam'ın isyancıların eline geçmesi, Fransız yönetimin dehşete düşürmüş ve Suriye'deki varlıklarını tehlikeli bir sürece sokmuştur. Bu sebepledir ki Fransız yönetimi Şam'ı geri alabilmek için şiddetli bir bombardımanla saldırıya geçmiştir. Hakimiyet-i Milliye gazetesi Şam'da yaşananları "Şam Ahvali Hakkında Tafsilat" başlığıyla 29 Ekim 1925 tarihinde ayrıntılı bir şekilde aktarmıştır. Haberin Times gazetesinden aktarıldığı belirtilmiştir: "Times gazetesi Şam'ın asilerin eline nasıl düştüğünü ve şimdi vaziyetin ne halde olduğunu anlatıyor." Hayfa muhabirinin Times'a aktardığı bilgilere dayanan habere göre: "Pazartesi günü öğleden sonraya kadar Şam şehrinin büyük bir kısmı asiler ve igtişaşcıların elinde idi." Şam'daki 3000 kişilik Fransız kuvvetleri ise merkezi binaları elinde bulundurarak Salihiye tepesine konumlanmış bir şekilde şehri topa tutmuştur. Şehre giriş ve çıkışların ise mümkün olmadığı ve demir yolunun tahrip edildiği bildirilmiştir. Şam'a güney mahallelerine gizli bir şekilde dahil olan Dürzi grupları da barikatlar kurarak Fransız kuvvetlerine saldırılarda bulunmuşlardır: "Hükümet binalarına yerleşmiş olan Fransızlar üzerine her taraftan ateş açılmıştır. Salhiye'de ki Fransız topçusu bütün gün ve bütün gece asi mahalleyi bombardımana devam etmiştir." Silah ve teçhizat üstünlügüne sahip olan Fransız birlikleri gece gündüz süren top atışları ve zırhlı otomobillerin vermiş olduğu güç ile Dürzi ve isyancı grupları bastırabilmiştir. Fransa'ya oldukça zor duruma sokan bu gelişmelerin, Fransız basını tarafından örtülmeye çalışıldığı bildirilmiştir. Ayrıca Türk Sözü gazetesinden aktarılan bir diğer bilgide: "Şam On bin Frank Cezaya Mahkum" başlığıyla verilen haberde Dürzilerin Fransızlara olan saldırılarında Şam halkının da yardım ettiği ve buna karşılık Fransızların şehri bombardımana tuttuğu bildirilmiştir: "Eşraf Fransızlara müracaat etmektedir. Fransızlar Şam şehrinden bir hafta zarfında verilmek üzere on milyon frank ve beş bin silah tazminat talep etmişlerdir." Ayrıca Fransızların, Halep şehrine büyük kuvvetler gönderdiği ve Hama şehrinde tutuklamalar gerçekleştiği bildirilmiştir. Şam köylerinin

${ }^{36}$ Suriye Vukuatı, Hakimiyet-i Milliye, 28 Ekim 1925.

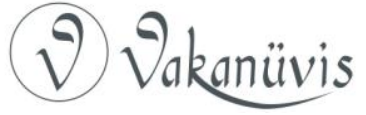


Dürzüler elinde olduğu ve ahalinin de isyana iştirak ettiği yine aktarılmıştır. Daily Mail gazetesinden aktarılan bilgilerde ise Fransız yönetimindeki Suriye durumun oldukça kötü olduğu ve Fransız bombardımanında iki binden civarında kişinin enkaz altında kaldığı bildirilmiştir. $^{37}$

Fransız kuvvetleri, Şam'a hakim olsalar da bu durum çok sürmemiş ve Şam yeni bir isyana sahne olmuştur. 16 Kasım 1925 tarihinde Hakimiyet-i Milliye'de aktarılan habere göre Şam'da yeni cereyanlar gerçekleşmektedir: "Şam yeniden bir paniğe sahne oldu her gün yeni Fransız kıtaları gelmektedir." Chicago Tribune gazetesinden aktarılan bilgide Şam'da yeni bir ihtilalin başladığı bildirilmiş ve Şam'ın son durumu şu şekilde tasvir edilmiştir:

"Binlerce tüccar dükkanlarını kapayarak firar ettiler, her gün yeni Fransız kıtaatı vasıl olmaktadır. Şam adeta taht-ı muhasarada bir belde şeklini almıştır. Her sokakta her caddede siperler vücuda getirilerek makineli toplar vazi edilmiştir. El hasıl cihanın en eski şehri şimdi en yeni usulde bir müstahkem karargah manzarası irae ediyor."

Habere göre Şam'da gerçekleşen yeni ihtilalin merkezinde: "evvelce Milletperver Halk Fırkası reisi olduğu halde şimdi isyan ve şekavet halinde" olan "Bekri" yer almaktadır. Bekri isimli zat: "Kendisini Şam Cumhuriyeti reisi ilan eylemiştir." Aynı zamanda ordunun kumandanı ve hükümetin başı olan Bekri'nin 4000 kişilik kuvvetiyle Şam şehrini elinde tutamayacağını anlaması üzerine kendine merkez olarak Humus şehrini tutacağı iddia edilmiştir. Dürzi güçleriyle de irtibat kurmak isteyen Bekri'nin Fransız kuvvetleri sebebiyle bu arzusunda başarılı olamadığı ancak Humus şehrini ele geçirip Cemiyet-i Akvam'ı Suriye'de yaşanan olaylara müdahil kılmak istediği belirtilmiştir. ${ }^{38}$

Suriye'de isyanın devam ettiğine dair bir başka haber ise 17 Teşrin-i Sani 1925 tarihinde Hakimiyet-i Milliye'de "Suriye Hakkında" başlığıyla verilmiştir. Daily Mail gazetesine göre: "Suriye'nin muhtelif şehirlerinde Fransızlara karşı kıyam tekrar tevsi' etmiştir." İsyancı kuvvetlerin Beyrut'u ele geçirmeye çalıştıkları ve Şam-Beyrut

\footnotetext{
${ }^{37}$ Şam Ahvali Hakkında Tafsilat, Hakimiyet-i Milliye, 29 Ekim 1925.

${ }^{38}$ Suriyeliler Cumhuriyet İlan Ediyor, Hakimiyet-i Milliye, 16 Kasım 1925.
}

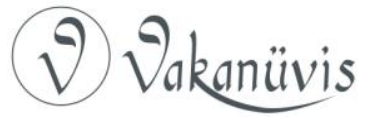


demiryolunu kesmeye çalıştıkları bildirilmiştir. ${ }^{39}$ Büyük isyanlarla geçen 1925 yılında isyanların artık sona erdiğini ve sükûnetin tekrar sağlandığına dair son haber ise 15 Kanunu Evvel 1925 tarihli Hakimiyet-i Milliye'de "Suriye Hakkında" başlığıyla verilmiştir. Fransız idaresinin yaptığı açıklamaya göre Suriye'de tam bir hakimiyet ve sükûnet sağlandığı bildirilmiştir. Ayrıca Şam'ın doğusunda bir Fransız taburunun imhasına dair bir iddiada bulunan İngilizlerin bu iddialarının doğru olmadığı bildirilmiştir. ${ }^{40}$

\section{Yılı İsyanları}

1926 yılındaki gelişmelere baktığımızda ise, Fransızların direnişin bastırıldığına dair iddialarının gerçeği yansıtmadığı görülmektedir. Haberleri incelediğimizde direnişin tüm Suriye'de dönem dönem devam ettiğini görebilmekteyiz. 13 Ocak 1926 tarihinde Ikdam'da "Suriye Havadisi" başlığıyla yayınlanan haberde, Suriye'de karışıklıkların tekrar başladığı bildirilmiştir. Intilalcilerin ele geçirdiği bölgelere Fransızların top ve uçak saldırılarıyla yoğun bombardıman gerçekleştirdiği aktarılmıştır. Fransız yönetimine karşı direnişe devam eden Dürzilerin amaçlarının Fransız destek kuvvetleri gelmeden Cebel-i Lübnan'da bulunan Dürziler ile birleşmek olduğu iddia edilmiştir. Ancak bu hedefleri gerçekleşememiştir:

"Çünkü evvela ahaliden mukavemet gördüler. Saniyen Cebel-i Lübnan'da ki Dürzilerin ekseriyesi tahsil ve terbiye görmüş ve hükümetçe mevki ve memuriyet almış kişilerden teşekkül olduğundan kendilerine teklif olunan ittihadı kabul etmediler. Bilahare yetişen Fransız kuvvetleri ahalinin kuvveti ile bila ittihat erbabı kıyamı Cebel-i Lübnan'dan çıkarmışlardır. ${ }^{\prime 41}$

Çatışmaların devam ettiğine dair bir başka haberde ikdam'da yer almıştır. 25 Ocak 1926 tarihli habere göre Şam'da çatışmalar devam etmektedir. Fransız kuvvetleri mevkilerinden, isyancıları top ve mitralyöz ile vurmaya devam etmektedir. ${ }^{42} 23$ Şubat 1926 tarihinde ise Hakimiyet-i Milliye gazetesi "Suriye'de Fransızlar" başlıklı haberiyle bölgede yaşanan çatışmaların devam ettiği ve Fransızların yaptıkları

\footnotetext{
${ }^{39}$ Suriye Hakkında, Hakimiyet-i Milliye, 17 Kasım 1925.

${ }^{40}$ Suriye Hakkında, Hakimiyet-i Milliye, 15 Aralık 1925.

${ }^{41}$ Suriye Havadisi, İkdam, 13 Ocak 1926.

${ }^{42}$ Suriye Haberleri, ỉkdam, 25 Ocak 1926.
}

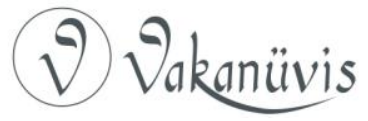


açıklamada çeteleri devamlı bir surette takip ettikleri bildirilmiştir. Yine Fransız iddiasına göre: "iki mühim reis-i dini, Müslim ahaliyi sulha davet sadedinde nutuk irat etmişlerdir." ${ }^{\prime 3}$

Şam ise büyük bir direnişe sahne olmuş ve Hakimiyet-i Milliye "Suriye'de Vaziyet" başlığıyla 6 Mart 1926 tarihinde Şam'daki son durumu aktarmıştır. Habere göre birçok gazete kapatılmış ve Meclis'in feshedileceği duyurulmuştur. Şam'daki son durum şu şekilde aktarılmıştır: "Şam'da vaziyet gittikçe fenalaşmaktadır. Top ve Silah sesleri etrafı kaplamıştır. İktisadi hayat felce uğramıştır.," ${ }^{44}$

Şam'a dair bir başka gelişme ise 14 Mart 1926 tarihine "Suriye'de Neler Oluyor" başlığıyla Vakit'te yer almıştır. Haberde ilk olarak Dürzilerin Şam şehrine olan saldırılarının devam ettiği aktarılmıştır. Dürzilerin, bilhassa Fransız taraftarı olan zengin kesimi yağma ettikleri kimi zenginleri ise alı koydukları haberde yer almıştır. Ayrıca Şam ahalisinin Ermeni ve Çerkez baskısından ötürü çarşıları kapatmak zorunda kaldıkları aktarılmıştır. Çarşılar, Fransızların teminatı üzerine tekrar açılsalar da baskının devam ettiği aktarıımıştır: "Ermeni, Çerkez milletperverlerin yaptıkları zulüm yüzünden kaynayan çarşılar Fransızların teminatı üzerine tekrar açılmıştır. Mamafih işkence ve zulüm devam etmektedir." ${ }^{45}$ Çatışmaların yıprattı̆̆ Şam şehrinin, Mart ayındaki durumunu anlatan "Şam Viran Bir Köy Gibidir" haber ise 15 Mart 1926 tarihli Vakit'te yer almıştır. Haberin kaynağı Şamlı birinin Türkiye'deki akrabasına gönderdiği mektuba dayanmaktadır. Mektuba göre gazetelerde anlatılanlar Şam'da yaşananların ancak binde biridir. Şam'da tren hatları çalışmamakta ve Dürzi akınları devam etmektedir. Yıkım sadece merkezde değil civar köylerde de gerçekleşmiş bulunmaktadır: "Şam etrafındaki bütün köylerde hayır kalmamıştır. Hepsi yıkılmış ve yahut yanmıştır." Mektupta şu ilginç tasvirde yer almaktadır: "Şam bugün viran bir köy gibidir. Ahali ekseriyetle şuurlarını kaybetmiş, haddinden ziyade rakı içerek sarhoş olmuş gibidir." ${ }^{\prime 6}$ Şam'a dair bir başka haberde 14 Mayıs tarihine aittir. Hakimiyet-i Milliye'de "Şam'daki Teşebbüs" başlığıyla verilen haberde

\footnotetext{
${ }^{43}$ Suriye'de Fransızlar, Hakimiyet-i Milliye, 23 Şubat 1926.

${ }^{44}$ Suriye'de Vaziyet, Hakimiyet-i Milliye, 6 Mart 1926.

${ }^{45}$ Suriye'de Neler Oluyor, Vakit, 14 Mart 1926.

${ }^{46}$ Şam Viran Bir Köy Gibidir, Vakit, 15 Mart 1926.
}

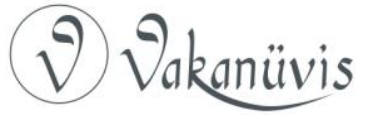


Dürzilerin Şam'ı tekrar ele geçirme girişiminde bulundukları ve bu girişimin başarısız olduğu bildirilmiştir. ${ }^{47}$

Dürzilerin, isyanın ilk evrelerinde ele geçirdikleri mevkilerden biri olan Suveyde'yi ele geçirmek üzere düzenlenen Fransız harekâtı ise 15 Mayıs tarihinde İkdam'a yansımıştır. "Suriye Muharebeleri" başlığıyla aktarılan haberde Suveyde bölgesinin Fransızlar tarafından nasıl alındığı aktarılmıştır. Söz konusu harekât için Fransızlar: "Birçok menzilli toplar ile dağ topları, zırhlı otomobiller ve tanklar ile mücehhez birkaç taburdan müteşekkil" bir orduyla harekete geçmişlerdir. Yoğun bir bombardımanın ardından çekilmek zorunda kalan isyancılar bölgelerini terk etmek zorunda almışlardır: "Erbab-ı kıyam ve ahali bu ateş karşısında çekiliyor. Tahliye edilen yerleri kuvvey-i askeriye suhuvetle işgal ediyor." Fransızların, Dürziler karşısındaki askeri üstünlükleri isyanı zor durumda bırakmaktadır. ${ }^{48}$

Hama'ya dair gelişmeler ise 4 Haziran 1926 tarihinde Ikdam'ın "Suriye Vekayı" başlıklı haberiyle aktarılmıştır. Haberde Hama'da yaşanan bir vakıa ayrıntılı bir şekilde verilmiş bulunmaktadır. Bahsedilen husus Hama şehrine yakın bir kasabadaki karakola yapılan baskındır. Haberde karakolun kumandanı olan Çerkez Abdullah'ın ihtilalcilere destek verdiği iddiasıyla bir şahsı tutuklaması ve bu şahsın özgürlüğüne kavuştuktan sonra topladığı bir çeteyle intikam almak için karakola saldırması aktarıımıştır. Söz konusu olayın dahi Türk basınında yer bulması Suriye'de yaşanan gelişmelere karşı kamuoyunun ilgisini göstermektedir. Haberin devamında ise Halep ve Hama'da çatışmaların devam ettiği aktarılmıştır. ${ }^{49}$ Şam'da isyanın yedi günlük bir sessizlik içine girdiği, i̇kdam gazetesinde "Suriye'de İsyancıların Mühim Mutalebatı" başlığıyla aktarılmıştır. 19 Haziran 1926 tarihli habere göre: "Şehir yedi gün mütemadiyen müteallik bir sükûn geçirdikten sonra birden bire tekrar hareket-i kıyama başlamıştır." Yedi günlük sükûnetin sebebinin ise yeni teşkil edilmiş olan hükümetten ne gibi sonuçlar elde edileceğini görmek için olduğu iddia edilmiştir. Ancak bekledikleri sonuçları alamayan isyancılar tekrar saldırılara başlamıştır. Ayrıca isyancılar, Şam sokaklarına 11 maddelik bir beyanname

\footnotetext{
${ }^{47}$ Şam'daki Teşebbüs, Hakimiyet-i Milliye, 14 Mayıs 1926.

${ }^{48}$ Suriye Muharebeleri, ikdam, 15 Mayıs, 1926.

${ }^{49}$ Suriye Vakayı, İkdam, 4 Haziran 1926.
}

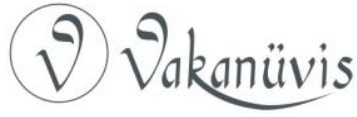


aşmışlardır. Eğer bu istekleri kabul görmezse isyana devam edeceklerini ifade etmişlerdir. Beyannamede yer alan maddelerde, Fransız ordusunun Suriye'yi terki, tazminat ve Suriye'nin bütünlüğü yer almaktadır. $^{50}$

Türk basınına yansıyan bir başka konu ise Şam hükümetinde yer alan üyelerin isyancılarla kurdukları irtibata dairdir. Fransızlar tarafından bu durumun tespit edilmesi üzerine kabine dağıtılmıştır. 3 Temmuz 1926 tarihli "Suriye Nazırı" başlık Hakimiyet-i Milliye haberinde Fransız kuvvetlerinin farklı bölgelerde ortaya çıkan intilalcilerle baş etmekte zorlandığı ve Şam kabinesinde ihtilalcilerle işbirliği tespit edildiğinden kabinenin dağıtıldığı aktarılmıştır. ${ }^{51}$ Konuyla ilgili bir diğer haber ise Hakimiyet-i Milliye'de "Suriye'deki Kabine" başlıklı 6 Temmuz 1926 tarihli haberde Guta'da İhtilalcilerle müzaheret eden kabine üyelerinin görevden alındığı bildirilmiştir. Haberde konu olan diğer bir mevzu ise çetelerle mücadele eden Fransız birliklerinin yerel halka uyguladıkları zulümlere dairdir. Çeteleri yakalayamayan Fransız birlikleri uğradıkları zararın bedelini civar köylerden çıkarmaya çalışmışlardır: "Liva istasyonunu çeteler kamilen yakmışlardır. Çeteleri takibe çıkan müfrezeler çeteleri bulamayınca bir iş yapmış olmak için Liva ve Beni Osman köylerini tevkif ve yanan binanın bedeli olan 3000 Türk altını ile iki yüz tüfenk teslimini talep etmişlerdir." ${ }^{52}$

Şam'da direnişle ilgili bir başka haber de 26 Temmuz 1926 tarihinde "Şam'da Muharebeler Devam Ediyor" başlığıyla verilmiştir. Haberde: "Suriyeliler Fransızları taciz için hiçbir fırsatı kaçırmıyorlar. Şam sokaklarında yeni müsademeler vuku bulmuştur." ifadeleriyle Şam'daki isyanların devam ettiği aktarılmıştır. Fransız kuvvetleriyle Şamlı direnişçiler arasında gerçekleşen çatışmalar sokaklara yansımış ve Fransız kuvvetleri direnişçilerle göğüs göğüsse çarpışmak zorunda kalmıştır. Şam halkı ile ilgili şu tespitlere değinilmiştir:

"Iş ve güçleri az çok yoluna girmeye başlamış olan ahali; söndürülmüş olduğuna hükmettikleri ateş-i ihtilalin şehir dahiline kadar tekrar sirayeti, endişelerini dolayısıyla zararlarını mucip olmuştur. Şam çarşııı baştan başa dolaşılmış olsa alışveriş eden

\footnotetext{
${ }^{50}$ Suriye'de İsyancıların Mühim Mutalebatı, İkdam, 19 Haziran 1926.

${ }^{51}$ Suriye Nazırı, Hakimiyet-i Milliye, 3 Temmuz 1926.

${ }^{52}$ Suriye'deki Kabine, Hakimiyet-i Milliye, 6 Temmuz 1926.
}

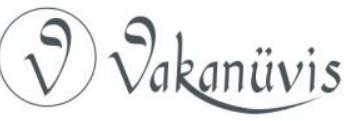


kimseye tesadüf edilmez, herkes kahvelere dökülmüş dün ne olmuş? Ne vukuat vardır diyerek birbirlerini vekayıden haberdar eyliyor. Gazeteler, sansürün ve Dıvan-ı Harbin verdiği ağır cezaların ürktükleri için bir şey yapamıyorlar. Kaydettikleri vakayı tebligat şubesinin verdiği resmi bir harp raporundan ibaret."

Şam halkının ihtilali desteklediğinin anlaşılmasının üzerine şehrin bazı mahallelerinin hakim noktalarına toplar yerleştirilmiştir. Ayrıca intilali yönettikleri gerekçesiyle birçok kişi de tutuklanmıştır. Fransız ordusunun hareket etmesi üzerine civar köylüler dağlara çekilmiş ve eli silah tutan köylüler Fransız müfrezesine karşı koymaya çalışmışlardır. "Kuvvetin geleceğinden haberdar olan köylüler bütün eşyalarını dağlara kaldırmışlar ve eli silah tutanlar müfrezenin yolunu tutmuşlar, miktarı yüz elliyi tecavüz etmeyen müfrezenin pişdarları ile yarım saat kadar çarpıştıktan sonra çekilmiştirler." ${ }^{13}$

Kısa bir süre sonra ise Şam civarındaki isyancı grupların Şam'ı kuşatmaya çalıştıkları ve girişimin Fransızlar tarafından engellendiği Hakimiyet-i Milliye'nin 27 Temmuz tarihli "Şam ihata Ediliyormuş" haberine yansımıştır. ${ }^{54}$ Temmuz ayındaki çatışmalara dair son haber ise 30 Temmuz 1926 tarihinde Hakimiyet-i Milliye gazetesinin "Suriye'de Fransızlar" başlığıyla verilmiştir. Hama ve Humus'da çatışmaların devam ettiği ve Fransızlarla işbirliği içinde olan Humus mutasarrıfına karşı suikast girişiminde bulunulduğu haberde aktarılmıştır: "Humus ve Hama mıntıkaları tekrar ihtilal ve iğtişaşlara sahne olmaya başladı. Arap çeteleri zayıf Fransız karakollarına baskınlar yaparak iz'açatta bulunuyorlar." Buna karşılık Humus mutasarrıfı Ali Fevzi Bey yerel ahaliden gönüllüler toplayarak, isyancılar üzerine sevk etmeye çalışmıştır. İsyancı liderler Ali Fevzi Bey'e bir mektup göndererek bu işten vazgeçmesini Fransızlarla iş tutarak "memleketinin ve milletinin zararına" çalışmamasını tavsiye etmişlerdir. Ali Fevzi Bey'in, intilalcilerin bu teklifini reddetmesi üzerine İhtilalciler bir fedai göndermiş ve bu fedai Ali Fevzi Bey'i iki yerinden hançerleyerek ağır bir şekilde yaralamıştır. Mutasarrıfın hayatı tehlikeli bir hal almıştır. Fedai ise yakalanmış ve bu işi "vatanı için yaptığını söylemiştir." Halep civarında ise çatışmaların devam ettiği ancak silah bakımından üstün

\footnotetext{
${ }^{53}$ Suriye'de Muharebeler Devam Ediyor, Hakimiyet-i Milliye, 26 Temmuz 1926.

${ }^{54}$ Şam Ihata Ediliyormuş, Hakimiyet-i Milliye, 27 Temmuz 1926.
}

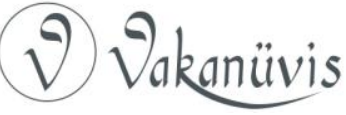


olan Fransızların yaşanan çatışmalarda üstün geldiği de bildirilmiştir. Ayrıca sık sık Şam'a baskınların gerçekleştiği aktarılmıştır. ${ }^{55}$

Ağustos ayı da isyanların yoğun yaşandığı bir dönem olarak karşımıza çıkmıştır. 2 Ağustos tarihli Hakimiyet-i Milliye'de "Muharebeler Devam Ediyor" başlıklı haberde Halep ve Şam'da çatışmaların devam ettiği aktarılmıştır. Fransızların gerçekleştirdiği ağır bombardımana rağmen isyanın Halep'te devam ettiği yazıımıştır:

"Halep'in şimal mahallelerine girmeye muvaffak olan bir çete heyeti Fransızların mezkur mahalledeki askerlerini basarak bir miktar efradı öldürmüşler ve diğer bir kısım efradat da firara muvaffak olmuştur. Fransızlar bunun üzerine civarı top ateşine almışlardır."

Şam'ın ise yaşanan yoğun bombardımanın ardından büyük bir yıkım yaşadığı aktarılmıştır:

"Dürzilerle Fransızlar arasında birbirini müteakip vukua gelen muharebeler neticesinde Şam yalnız ismini muhafaza etmiştir. Eski mebaniye ait hiçbir eser kalmamıştır. Şimdiye kadar inzibat ve asayişin edilememesinden ahali belde-i Beyrut ve Halep taraflarına hicret etmektedirler. Bunlar meyanında beş yüz hane halkının Antakya'ya gelmek üzere oldukları söylenmektedir."

Yaşanan bu büyük yıkımın ardından bölge halkının Cemal Paşa dönemini hasretle andıkları aktarılmıştır: "Mukaddema Cemal Paşa'ya lanet okuyan halk nedem ve son derece pişman olmakta ve ismini hasretle yad etmektedirler." 56

Şam'daki direnişe dair bir diğer haberde "Suriye'de Şiddetli Çatışmalar Oluyor" başlığıyla 3 Ağustos tarihinde Hakimiyet-i Milliye'de yer almıştır. Haberde Şam civarında şiddetli çatışmaların devam ettiği aktarılmıştır: "Şam civarında on beş bin kişilik Fransız ordusuyla yerliler arasında şiddetli muharebeler devam ediyor." Ayrıca Şam direnişinin reislerinin daha rahat hareket edebilmek için eşlerini ve çocuklarını çöllerdeki bölgelere gönderdikleri aktarılmıştır. ${ }^{57}$ Çatışmaların devam etmesi üzerine Fransız yönetimi Suriye'ye yeni askerler sevk etmek

\footnotetext{
${ }^{55}$ Suriye'de Fransızlar, Hakimiyet-i Milliye, 30 Temmuz 1926.

${ }^{56}$ Muharebeler Devam Ediyor, Hakimiyet-i Milliye, 2 Ağustos 1926.

${ }^{57}$ Suriye'de Şiddetli Muharebeler Oluyor, Hakimiyet-i Milliye, 3 Ağustos 1926.
}

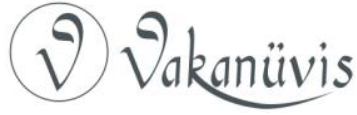


durumunda kalmış ve çatışmalar Şam'ın doğusunda yoğunlaşmıştır. 16 Ağustos tarihli haberde "Suriye'de Fransızlarla Yerliler Arasında" başlığıyla Şam'ın doğusunda bulunan Guta bölgesindeki çatışmalar aktarılmıştır. Fransızlar Fas'tan celp ettikleri kuvvetlerle takviye olunan yirmi bin bir kişilik orduyla 19 Temmuzda Guta üzerine harekete başlamışlardır:

"Kıtaatı askeriye tanklar, tayyareler, zırhlı otomobiller vesairede iştirak etmiştir. Kitaat hareket etmeden evvel Guta mıntıkasını topçu ateşi altına almıştır. On binden fazla top mermisi endaht olunmuştur. Muharebe tam üç gün devam etmiştir. Bu üç gün muharebede Fransızlar beş bine yakın telefat, $i k i$ binden ziyade mecruh ve esir vermişlerdir. Bu üç gün muharebede ihtilalciler harikulade azimle ve cesaretle dövüşmüşler."

Ancak Fransızların askeri üstünlüğü karşısında Guta bölgesini daha fazla savunamayan isyancılar, bölgeden çekilmek zorunda kalmışlardır. Guta bölgesini ele geçiren Fransızlar: "Bütün köyleri taş taş üstünde bırakmamak şartıyla ihrak ve imha etmişlerdir. Bu havalide insan veya hayvan neye rast gelmiş ise kamilen itlaf edilmiştir." Üç gün sonra intilalciler Guta üzerine harekete geçmişler bunun üzerine Fransızlar Şam'a ricat etmişlerdir. Şam'a çekilen Fransızlar Şam eşrafını toplayarak intilalcilerle bir sulh zemini hazırlanmasını teklif etmişler ve eşraftan oluşturulan heyet Guta'ya ihtilalcilerle görüşmeye gitmiştir. Haberin devamında, Fransızların Şam halkına uyguladıkları baskılardan bahsedilmiş ardından Şam halkıyla ilgili şu tespit yapıımıştır: "Şam ahalisi hemen kamilen denilecek derecede musellah bulunuyorlarmış. Hatta geceleri çetelere iltihak ederek gündüzleri de Şam'daki işleriyle meşgul olan bir çok ihtilalci varmış." Haberdeki bu kısım ihtilalin halkın genelinde benimsendiğini ve direnişin kararlııkla devam ettirildiğini göstermektedir. Haberde yer alan bir başka bilgi ise Havran halkıyla ilgilidir. Habere göre Havran halkının da bölgedeki Dürzilerle bir ittifak gerçekleştirerek, Fransızlar üzerine bir harekâta geçecekleri iddia edilmiş:

"Havran mıntıkası ahalisi de suret-i katiye de Dürzilerle ittifaka karar vermişler. Fakat meydanlardaki harmanlarının kaldırılmasını bekliyorlarmış, harmanlar çıktıktan sonra Dürzilerle birleşerek Fransızlara karşı muharebe edeceklermiş."

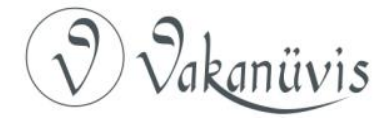


Kimi Dürzi köylerinin Fransızlara karşı olan direnişlerinde en büyük etkenin Fransız yönetiminin Dürzi köylerine karşı gerçekleştirdikleri baskının olduğu iddia edilmiştir. ${ }^{58}$

Ağustos ayının son günlerinde ise Hakimiyet-i Milliye'de Fransız Komiserinin beyanatı yer almıştır. 29 Ağustos tarihli habere göre Suriye Fevkalade Komiseri Bonson yaptığı açıklamada Suriye'de askeri operasyonların son bulduğunu açıklamıştır. Ayrıca Suriye'de milli bir hükümet ve düzen için Fransa'nın yardımının zorunlu olduğunu belirtmiştir: "Suriye'nin kendi toprağında kendi zabıta kuvvetleri ve kendi vesaitiyle idare olunan müstakil ve hakiki bir hükümet haline gelmesi için muavenet etmek mecburiyetindedir." ${ }^{159}$

Ancak Suriye Fevkalade Komiserinin açıklamalarının gerçeği yansıtmadığı 11 Eylül 1926 tarihli haberde görülmektedir. "Suriye'de Yerlilerle Fransızlar Arasında" başlığıyla verilen haberde çatışmaların devam ettiği görülmektedir. Haberde Şam'da gerçekleşen büyük bir çatışmaya dair ayrıntılar da aktarılmıştır. İhtilalcilerin gerçekleştirdikleri planda Fransız birlikleri ve Ermeni çeteleri ağır bir darbe almışlardır. Çatışmanın ayrıntılarına göre Guta mevkiine yerleşen ihtilalcilerin hazırlık yapmaya başladıkları sırada Fransızlarla işbirliği yapmakta olan üç yüz kadar Dürzi ilk olarak ihtilalcilerin bölgesine gelmişler ardından Fransız birliklerine bölgenin durumunu arz etmişlerdir. Bunun üzerine harekete geçen Fransız birlikleri ihtilalcileri dağlara çekilmeye mecbur bırakmıştır. Muharebe bir gün bir gece sürmüştür. İhtilalcilerden dört yüz kadarının teslim olduğu ve teslim olan bu kişilerin Şam'da büyük bir plan gerçekleştirdikleri anlatılmıştır:

"Şam'da teslim olanlar ki -dört yüz kişiye gariptir- silahları alındıktan sona şehirde serbest bırakıldılar. Bunu daha evvel düşünen bu kısım teslim oldukları salı gecesi tedarik eyledikleri silah ile gafil bir vaziyette Meydan Mahallesinde yatan Ermeni ve Çerkez alayları üzerine hücum ederek çadırları yaktılar uykudan gafil kalkan askerler yarım saat kadar birbirlerini süngülediler ve ihtilalcilerde diğer mahallelerde ki Fransız karakollarına ayrı ayrı baskın verdiler."

\footnotetext{
${ }^{58}$ Suriye'de Fransızlarla Yerlilerle Arasında, Hakimiyet-i Milliye, 16 Ağustos 1926.

${ }^{59}$ Suriye Fevkalade Komiserinin Beyanatı, Hakimiyet-i Milliye, 29 Ağustos 1926.
}

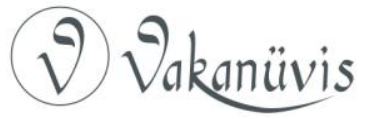


Yaşanan bu olayın Fransızları dehşete düşürdüğü ve olayın ayrıntılarını örtmeye çalıştığı iddia edilmiştir. Çatışmalarda Ermeni ve Çerkezler dört yüz, Fransızlar elli ölü ve yaralı vermiştir:

"Bütün şehri sarsan bu gece müsademelerinde ihtilalciler yüz maktul, gafil avlanan Ermeni ve Çerkezler dört yüz ve Fransızlarda elli maktul ve mecruh verdiler." ${ }^{\prime 60}$

intilalcilerin Fransız kuvvetlerine karşı gerçekleştirdikleri başarıları çatışmalarından daha mühim olan ise ihtilalcilerin yeni bir teşkilatlanma içerisine girmeleridir. "Suriyelilerin İdari Teşkilatı" başlığıyla verilen kısımda ise ìhtilalcilerin Milli Mücadele dönemindeki usulleri uygulamaya çalıştıkları ifade edilmiştir: "Suriye ihtilalcileri Türk vatanperverlerinin kurmuş oldukları ihtilal usullerini harfiyen tatbik edemezlerse bile kısmen bunları tatbik etmektedirler." İhtilalciler "Şeyh Harinin riyasetinde bir Büyük Millet Meclisi" ve dört kolordu ile bir başkumandanlık tesis etmiştir. Kolordu kumandanları sabık Türk ordusu binbaşılarından Fevzi Kavukçu ve Miralay Yahya Hayati gibi kişilerden oluşmuştur. Ayrıca mezkur meclis ìstiklal madalyaları takdim etmiştir. Suriye ihtilalcilerinin Anadolu'da gerçekleşen Milli Mücadele hareketini örnek almaları dikkat çekicidir. ${ }^{61}$

Bu konuya dair bir başka haberde 13 Eylül 1926 tarihinde İkdam'da yer almıştır: "Suriye intilalcilerinin Programları Nedir?" başlığıyla verilen bu haberde ihtilalcilerin faaliyetleri ve amaçları incelenmeye çalışılmıştır. "Suriye intilalcileri Türk vatanperverlerinin kurmuş oldukları ihtilal usullerini harfiyen tatbik edemezlerse bile kısmen bunları tatbik etmektedirler." intilalcilerin bu usullerle zafere ulaşacaklarına inandıkları belirtilmiştir. Milli Mücadeleyle benzer bir şekilde bir Büyük Millet Meclisi de oluşturulmuştur. ${ }^{62}$

\section{7'de İsyan Sonrası Durum}

1927 yılına geldiğimizde ise Fransız yönetiminin askeri operasyonlarının ardından Suriye'de gerçekleşen isyanlar kontrol altına alabildiği görülmüştür. İsyanların bastırılması için Fransız yönetimi sert önlemler almış ve şehirleri yakıp yıkma pahasına gerçekleştirdiği

\footnotetext{
${ }^{60}$ Haberde Fransızların ölü ve yaralı sayısı net olarak verilmemiştir.

${ }^{61}$ Suriye'de Fransızlarla Yerlilerle Arasında, Hakimiyet-i Milliye, 13 Eylül 1926.

${ }^{62}$ Suriye intilalcilerin Programları, İkdam, 13 Eylül 1926.
}

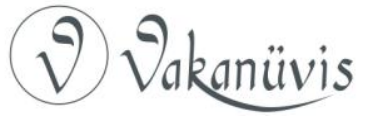


bombardımanlarla şehirleri kontrol altına alabilmiştir. Ancak yine de Fransız yönetimin, yeni bir isyanın çıkmasından korktuğu görülmektedir. Bu konuya dair haber Hakimiyet-i Milliye gazetesinde 21 Mayıs 1927 tarihinde "Suriye'de Yerlilerle Fransızlar Arasında" başlığıyla verilmiştir. Habere göre Fransız yönetimi, Şam'da yeni bir isyanın çıkmasından korkmaktadır. ${ }^{63}$ Şam'da sükûnetin sağlandığına dair haber ise 24 Temmuz 1927 tarihli ikdam gazetesinde "Suriye intilali" başlığıyla verilmiştir. Ayrıca haberde Şam'da idare-i örfiye ile birlikte geceleri sokağa çıkma yasağının da kaldırıldığı bildirilmiştir. ${ }^{64}$

İncelediğimiz haberlerin sunmuş olduğu tablo bize şunu göstermiştir ki, Suriye halkı Fransız yönetimini benimsememiş ve bağımsızlıkları için uzun bir mücadele içine girmiştir. Bilhassa Cebel-i Dürzi'de başlayan isyan kısa sürede Suriye'nin büyük şehirlerine yansımış ve Suriye halkı tarafından benimsenmiştir. İncelediğimiz yıllar içinde Suriye isyanlarının en güçlü olduğu dönem ise 1925 ve 1926 yıllarıdır. Bu dönemde güç kazanan direniş, Fransız yönetimini zor durumda bırakmıştır. Suriye'nin dört bir yanında isyanlarla karşılaşan Fransız yönetimi ise oldukça sert tedbirler almıştır. Fransız yönetiminin gerçekleştirdiği askeri operasyonlar, üstün silah gücü ve düzenli ordunun etkisiyle başarılı olmuştur. Ancak askeri operasyonlar sonucunda Suriye halkı büyük kayıplar vermiş ve Suriye şehirleri birer enkaza dönmüştür. ${ }^{65}$ Yıkıcı müdahalelerin ardından Suriye direnişi gücünü yitirmiş ve 1927 yılında Fransız yönetimi, Suriye üzerindeki hakimiyetini sağlamıştır.

Suriye direnişiyle ilgili dikkat çeken bir diğer husus ise isyancıların Anadolu Milli Mücadelesini örnek almaları ve benzer yöntemler uygulamalarıdır. Bu durum Suriye direniş̧̧ilerinin de aynı hissiyata sahip olduklarını göstermektedir. Suriye direnişinin başarısızlığındaki en önemli etkenlerden biri ise isyana komutanlık edecek askeri eğitime sahip kadroların yetersizliğidir. Düzenli ordudan yoksun olan Suriye direnişi, Fransa karşısında başarısız olmuştur.

\footnotetext{
${ }^{63}$ Suriye'de Yerlilerle Fransızlar Arasında, Hakimiyet-i Milliye, 21 Mayıs 1927.

${ }^{64}$ Suriye intilali, ìkdam, 24 Temmuz 1927.

${ }^{65}$ Suriye halkının o dönemde yaşadığı zulümler için bkz. Emir Şekip Arslan "Şehit Suriye" istanbul, 2014, s.21-71.
}

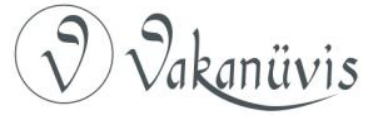


Cumhuriyetin ilk döneminde Türk basını, Suriye'de yaşananlar karşısında duyarsız kalmamış ve olayları en ince ayrıntılarıyla birlikte okuyucusuna aktarmıştır. Türk basınının kimi zaman isyancıları "mücahit" olarak adlandırması ve Suriye direnişine olan olumlu yaklaşımı, Türk-Arap ilişkilerindeki kırılmaların henüz Türk kamuoyunu etkisi altına almadığını göstermiştir.

\section{Türk Basınında Suriye Halkının Türkiye'ye Bakışı}

Suriye ile ilgili Türk basınına yansımış olan haberler incelendiğinde Suriye halkının Türkiye'ye olan meyilleri görülmektedir. Türk basınındaki haberler, Arap ulusalcılarının iddialarının aksine Suriye halkının Osmanlı dönemini sömürge dönemi olarak gördüklerine dair bir ifade taşımamaktadır. Türk basınına yansıyan haberlere göre Suriye halkı Türk yönetimine özlem duymakta ve Milli Mücadele'nin liderlerine sevgi beslemektedir. Dikkat edilmesi gereken bir başka nokta ise Suriye halkının Türk yönetimine olan yakınlığı hususunda verilen haberlerin, Hakimiyet-i Milliye gazetesi merkezli olmasıdır. Milli Mücadelenin sesi olan Ankara merkezli gazetenin, bu haberleri vermesi devletin ilk dönemki bakışını da sunmaktadır.

Suriye halkının Türk yönetimine olan meyli ve özlemi hakkındaki ilk haber 22 Şubat 1923 tarihinde Hakimiyet-i Milliye'de verilen "Suriye'de Vaziyet" başlığı altında "Kalbi bir mesele karşısında cebr" alt başlığıyla verilmiştir. Haberde Suriye bölgesinde Mustafa Kemal Paşa ve diğer büyük Türk kumandanlarının resimlerinin Suriye halkı tarafından dükkânlarına ve evlerine asıldığı bildirilmiştir. Buna karşılık Fransız yönetimi Mustafa Kemal Paşa ve Türk komutanlarına dair olan resimlerin asılmasını yasaklamıştır. Yine aynı şekilde Türk-Yunan savaşına dair afişlerin yasaklandığı da haberde bildirilmiştir: "Suriye'de Gazi Mustafa Kemal Paşa hazretleriyle diğer büyük Türk kumandanlarının resimlerine ve Türk- Yunan savaşına ait levhalar hükümet tarafından toplattırılmıs ve bir daha bu gibi resimleri asanlardan ceza alınacağı ilan edilmiştir." ${ }^{\prime 66}$ Haber incelendiğinde gördüğümüz tablo Suriye halkının Türk komutanlarına ve yönetimine olan saygısı ve meylidir. Mezkur dönemde, İslam dünyasının kahramanı

${ }^{66}$ Suriye'de Ahvali, Hakimiyet-i Milliye, 22 Şubat 1923.

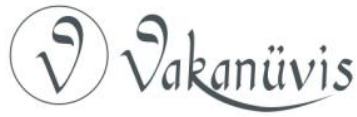


olarak görülen Mustafa Kemal Paşa'nın bir kısım Suriye halkında uyandırdığı duygu resimlere ve afişlere yansımıştır. Diğer dikkat çekici husus ise Türk-Yunan savaşına dair olan afişlerdir. Söz konusu afişlerde görülen tabloyu sadece Türk zaferine duyulan sevinç olarak yorumlamak eksik olacaktır. Burada dikkat edilmesi gereken nokta Türk-Yunan savaşındaki Türk zaferine duyulan sevincin Suriye halkının da direnişine bir gönderme olmasıdır.

5 Temmuz 1923 tarihinde İkdam'da "Lozan'da Suriye Heyet-i Murahhasının Beyanatı" başlığıyla verilen haber dikkat çekicidir. El Mukaddem gazetesinin Lozan'da bulunan bir muhabiri Suriye murahhaslarıyla bir mülakat gerçekleştirmiştir. Mülakat Emir Şekip $\operatorname{Arslan}^{67}$, Süleyman Kenan, İhsan Cabri beylerle gerçekleştirilmiştir. Mülakatta dikkat çekici hususlar dile getirilmiştir. Mülakatta heyet ilk olarak Lozan'a gelme sebeplerini açıklamaktadır. Aslında kendilerinin konferansa resmen çağrılmadıklarını ifade etmişlerdir:

“Lozan'a gelmekte ki maksadımız, Suriyelilerin hukukunu müdafaa ve şark meselesinin hali için toplanan herhangi bir konferansta fırsatı kaçırmamaktır. Resmen çağırılmamış isek de resmi heyet murahhasları nezdindeki mesaimiz büyük bir adım atmıştır."

Heyet hedeflerini şu sözlerle ifade etmiştir: "Tam istikbalimizin verilmesi, işgal kuvvetlerinin memleketimizden çekilmesi, Cemiyet-i Akvam'da ve hükümetler nezdinde mümessillerimiz bulunmasıdır." "Memleketimizin bir müstamere şeklinde, hatta İngiliz dominyonlarına müşabe bir vaziyette bulunmasına razı olmuyor." Heyetin kabul edebilecekleri son had ise: "Fransa ve Ingiltere ile menfaatlerini temin edecek hususi ittifaklar akdidir." şeklinde ifade etmiştir. Heyet, Fransa'nın son süreçte Suriye'de gerçekleştirdiği teşkilata halkın hatııın kazanma yolunda atılan adımlar olarak bakarken, Fransa'nın Suriye'ye tedrici bir istiklal vereceğine itimat etmiyorlar. Bilhassa Türkiye ile Fransa arasındaki sorunların azalmasından sonra bu ihtimalin zayıfladığını bildirmekteler. Mülakatın en hassas ve dikkat çekici kısmı ise Suriye murahhaslarıyla İsmet Paşa arasında gerçekleşen görüşmeye dairdir. Lozan konferansının ilk kısmında gerçekleşen bu

${ }^{67}$ Emir Şekip Arslan hakkında daha fazla bilgi için bkz. William Cleveland "Batı'ya Karşı islam Şekip Arslan'ın Mücadelesi" i̇stanbul, 2017.

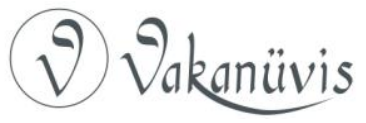


görüşmede Suriye heyeti, İsmet Paşa'dan Türkiye'nin bölgedeki hukuki haklarından Arap memleketleri adına feragat etmelerini istemiştir. Suriye heyetinden önce de bu talebin Mısır heyeti tarafından istendiği bildirilmektedir. Ve heyetin iddiasına göre İsmet Paşa, Arap memleketleri lehine hukuki haklardan feragat edeceklerini bildirmiştir. Ancak Lozan görüşmelerinin ikinci kısmında Türk heyeti, hukuki haklardan İngiltere lehine feragat etmiştir. Suriye heyeti şunu açık bir şekilde ifade etmiştir ki, kendileri de lehlerine olacak bir feragatin istiklali getirmeyeceğinin farkındaydılar ancak bu hakları müttefiklere karşı kullanabilecekleri bir koz olarak düşünmekteydiler. Bu konuyla ilgili ifadeler haberde şu şekildedir:

"Birinci Lozan konferansında Suriyeliler, Mısırlılar gibi, Türk heyet-i murahhasasından, Türkiye Arap memleketleri üzerindeki hukuki hakimiyetinden mezkur memleketler ahalisi lehine feragat ettiğine ve müttefiklere de onların istiklalini ilan etmiş bulunduklarını hatırlatacağına dair sarih beyanat almışlardır. ismet Paşa şifahi tasrihatılyada iktifa etmeyerek konferansa tahriri beyanname vermişti. Vakıa biz, Arap istiklalinin, Türkler tarafindan vuku bulacak beyanat ve ilan veyahut müttefiklerin kabul veya adem-i kabulüyle olunabileceğine kani değiliz. Ancak biz Türk heyeti murahhasasının beyanatını müttefiklere karşı kullandığımız siyasi edille berahin meyanına idhal etmiştik. Fakat ikinci Lozan konferansında müttefikler Türkiye'yi, hukukundan ahali lehine feragat ettiğini zikretmemeye ikna eylediler. Halbuki Türkiye'nin ahali lehine hukukundan feragatiyle şimdi isti'mal edilen alakadarlar lehine feragati tabiri arasında büyük bir fark vardır. Biz bu ciheti ismet Paşa'ya verdiğimiz bir takrirde izahla son tabirin ortaya müttefikleri de ithal ettiğini, bunun Suriyelilerin hürriyetine zarar verdiğini bildirdik ve evvelki beyanatta Israr-ı kabil değilse bu babdaki maddeyi, Türkiye'nin Arap memleketlerinde ki bütün hukukundan Misak-ı Milli dairesinde feragat ettiğini şekaline ifrağını rica eyledik. Heyet-i murahhasımız en son şekil olarak bunu kabul edebilir. İsmet Paşa verdiği cevapta heyet-i murahhasımızın mutalebenin tervici için bütün kuvvetini sarf edeceğini beyan, fakat müttefiklerle Türkiye arasında mevcuu mesaili kayd ve işaret etmiştir."

Mülakata göre Suriye ve Mısır heyetinin Türk heyetiyle yaptıkları görüşmelerde en büyük istekleri Türkiye'nin bölge üzerindeki haklarından yerel ahali lehine feragat etmesidir. Heyetin bu husustaki

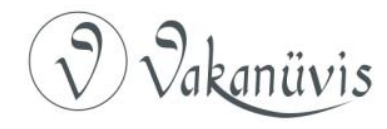


dayanağı ise son Osmanlı Mebusan Meclisi'nde kabul edilen Misak-ı Milli kararlarıdır. Misak-ı Milli'ye göre Arap nüfusun çoğunlukta bulunduğu işgal altındaki topraklarda, bölge halkının geleceği yine halkın kararıyla belirlenmeliydi. ${ }^{68}$ Türk tarafı ilk Lozan görüşmelerinde bu yönde bir tavır almıştır. Ancak Lozan görüşmelerinin ikinci kısmında durum değişmiş ve İtilaf güçlerinin baskısıyla Türk heyeti, İtilaf güçleri lehine bir feragatte bulunmuştur. Bu durum her halde Suriye ve Mısır heyetleri için bir sukut-u hayaldir. Suriye heyeti kendilerinin de ifade ettiği gibi Türkiye'nin haklarından feragatini Arap hakları lehine gerçekleştirmesi durumunda işgalin sona ermeyeceğinin farkındaydılar ancak bu onların kullanabilecekleri bir argüman olabilirdi. Ayrıca heyet Türkiye-Fransa arasında geçekleşen Türkiye-Suriye sınır meselesinin, Suriye ahalisini temsil eden hükümet ile gerçekleştirilmesini savunmuştur. ${ }^{69}$

20 Eylül 1923 tarihinde "Halep'te Istırap" başlığıyla Hakimiyet-i Milliye'de yer alan haberde Fransız yönetiminin yerli halka karşı gerçekleştirdiği baskılar ve halkın bu baskılardan kurtulmak ve Türk hakimiyetini tekrar sağlamak için yaptıkları çalışmalara yer verilmiştir. Habere göre Suriye'de Türklerin geri dönüşünü hedefleyen gizli bir teşkilat kurulmuştur. Fransız yönetimi ise söz konusu teşkilata üye olduğu iddia edilen 23 kişiyi Fransız idari mahkemesinde yargılamıştır. ${ }^{70}$

Hakimiyet-i Milliye'nin 23 Eylül 1923 tarihli "Suriye Haberleri" başlıklı yazısında dikkat çekici içerik Halep halkına dairdir. Haberde Halep ve çevre ahalisinin yüzde doksanlık kısmının Türkiye'ye bağlanma arzusunda olduğu bildirilmiştir. Haberde, "Halep ve civarı ahalisinin yüzde doksan beşi Türkiye'ye iltihak arzusundadır." iltihak arzusu önemli bir iddia olarak karşımıza çıkmıştır. Fransız yönetimi

\footnotetext{
${ }^{68}$ Misak-ı Milli'nin Arap nüfusun yaşadığı işgal altındaki Osmanlı topraklarına dair maddesi, "Mondros Mütarekesi'nin imzalandığı tarihte düşmanlar tarafından işgal edilmiş bulunan ve nüfusunun çoğunu Araplar teşkil eden Osmanlı imparatorluğu topraklarının "Mukadderatı", o topraklarda yaşayan halkın serbestçe beyan edecekleri oylarla ta'yin edilmek gerekir." Kaynak: Selahattin Tansel, "Mondros'tan Mudanya'ya Kadar" 3. Cilt, Ankara, 1978, s.18. ; Ayrıca bkz. Haluk Selvi, "Sorularla Türkiye Cumhuriyeti Tarihi, 2017 i̇stanbul, s. 51.

${ }^{69}$ Lozan'da Suriye Heyet-i Murahhasının Beyanatı, ikdam, 5 Temmuz 1923.

${ }^{70}$ Halep'te Istırap, Hakimiyet-i Milliye, 20 Eylül 1923.
}

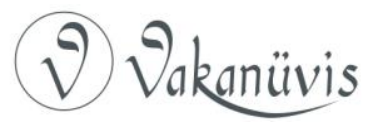


altındaki en önemli şehirlerden biri olan Halep'te yaşanan gelişmeler, Fransızları tedirgin etmektedir. Haber Halep halkının kıyam halinde olduğunu aktarmaktadır. Fransız birliklerinin ise bir tehlike anında Hama bölgesine çekilmesi kararlaştırılmış ve durum Paris'e bildirilmiştir. $^{71}$

23 Eylül 1923 tarihinde Hakimiyet-i Milliye'ye yansıyan diğer bir haber ise "Şam'da Bir Tezahür" başlı̆̆ıla verilmiştir. Haberin içeriği dikkat çekicidir. Çünkü İzmir'de neşir olunan Ahenk gazetesine, Şam'dan gelen bir mektupta Şam Sinaniye Camisi'nde toplanan halkın Türkiye yanlısı bir tutum içinde bulundukları anlatılmıştır:

"Müzafferiyet-i milliyemizin sene-i devriyesi günü Sinaniye Camiinde toplanan binlerce Müslüman huzurunda cami imamı tarafindan Türklügün alem-i İslam'a ifa ettiği ulvi hizmete ve Fransız istibdat ve mezalimine dair pek müessir muaza irad olunmuştur."

$\mathrm{Bu}$ hutbenin ardından camide bulunan halk galeyana gelerek casusluk yaptığı bilinen dört kişiyi döverek camiden dışarı atmıştır. "Heyecana gelen halk, Fransizlara casusluk etmekle maznun olup cemaat arasında mevcut dört melunu döverek camiden kovmuşlardır. Fransızlar bu casusları himayeye cesaret edememişlerdir." Şam'da gerçekleşen bu olay Şam halkının Osmanlıya olan özlemini göstermektedir. Oysa Arap milliyetçiliğinin merkezi olarak görülen ve Emir Faysal'ın krallığını ilan ettiği Şam şehrinde durumun keskin çizgilerle çizilemeyeceği görülmektedir. Hutbede Türk milletinin İslam alemine olan büyük hizmetleri anlatılmış ve Fransız yönetiminin gerçekleştirdiği mezalimlerden bahsedilmiştir. Ayrıca mektupta Fransızlara karşı Dürzilerin isyan hazırlığı içerisinde oldukları bildirilmiştir. Haberde yer alan ve oldukça da ilgi çekici olan bir haber başlığı da "Şam'da Ahır Yapılan Cami-i Şerif" tir. "Şam'daki Sultan Selim Caminin ahır yapılmak üzere kiraya verilmiş olmasını tenkiden Türk matbuatının neşriyatı Şamlılar tarafından büyük bir alaka ile takip edilmiştir."72

\footnotetext{
${ }^{71}$ Suriye Haberleri, Hakimiyet-i Milliye, 23 Eylül 1923.

${ }^{72}$ Şam'da bir Tezahür, Hakimiyet-i Milliye, 23 Eylül 1923.
}

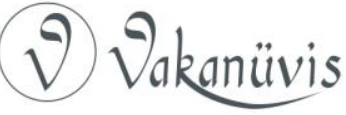


Halep halkının Türk yönetimine olan meyli hususunda bir başka haber ise 1 Teşrin-i Evvel 1923 tarihinde Hakimiyet-i Milliye'de "Suriye Mektubu" başlığıyla yayınlanmıştır. "Suriye'den bildiriliyor: Halep ve havalisindeki ahali Türkiye'yi muhteresane yad etmektedir." Yine bölgeden Halep'in Harm kazası kaymakamı olup daha sonra Beyrut'a geçen Akarlı Ekrem Bey'in aktardıklarına göre Halep ahalisi Türkiye'ye iltihak arzusundadır. Ayrıca Fransızlara karşı silahlı bir direniş de başlamıştır. Akarlı Ekrem Bey'in “... verdiği malumata nazaran ahalinin yüzde doksan beşi Türkiye'ye iltihak arzusundadırlar ve Fransızlara karşı son günlerde silahla kıyam halindedirler." Haberde aktarılan bilgiye göre Harm kazasının eski kaymakamının iddiaları Halep halkının Türk yönetimine olan meylini göstermektedir. Durumun kritik olduğunu gösteren bir başka delil ise Fransızların olaylar kontrolden çıktığı takdirde Hama bölgesine çekileceklerini açıklamalarıdır. ${ }^{73}$

4 Teşrin-i Evvel 1923 tarihinde Hakimiyet-i Milliye'de "Suriye Üzerindeki Gizli Emeller" başlığıyla yayımlanan haber oldukça önemlidir. Haberin önem arz etme sebebi ise Şerif Hüseyin'in Halep şehriyle ilgili olan endişeleridir. Londra gazetelerine yansıyan haberlere göre Şerif Hüseyin İngiltere Hariciye Nezaretine çektiği telgrafta, Ingiltere ile kendi arasında 1915 tarihinde gerçekleşen müzakerelerde Suriye'nin Irak hükümetine dahil olmasına dair olan kararı hatırlatmıştır. Ayrıca Şerif Hüseyin, Halep halkının günden güne Türkiye'ye olan ilgilerinin artmakta olduğunu hatırlatmış ve bu sorunun çözümünün bölgede müstakil bir Arap devletinin kuruluşu olduğunu bildirmiştir. Londra gazetelerine yansıyan iddialara göre Halep halkının Türkiye'ye olan bağlılığı devam etmekte hatta günbegün artmaktadır. Ve bu durum Şerif Hüseyin için bir endişe kaynağı haline gelmiştir. ${ }^{74}$

Bir diğer önemli haber ise 28 Ekim 1923 tarihinde Hakimiyet-i Milliye'de "Suriye Ahvali" başlıklı haber sabık Lazkiye mebusu Emir Şekip Arslan'ın Tevhid-i Efkar gazetesi muhabirine verdiği beyanattır. Emir Şekip Arslan I. Dünya Savaşı'ndan önceki çalışmalarıyla da tanınan bir zattır. Kendisi Türk ve Arap halklarının birbirinden ayrılmasına karşı çıkmış ve birlikteliği savunmuş bir Arap aydınıdır. Ömrünü bu birlikteliğe adamış olan Şekip Arslan, parçalanmadan sonra da Suriye

\footnotetext{
${ }^{73}$ Suriye Mektubu, Hakimiyet-i Milliye, 1 Ekim 1923.

${ }^{74}$ Suriye Üzerindeki Gizli Emeller, Hakimiyet-i Milliye, 4 Ekim 1923.
}

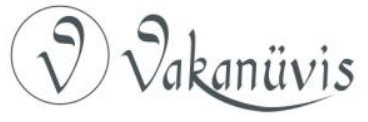


topraklarının kurtuluşu için mücadele etmiş ve yine kurtuluşun TürkArap birlikteliğinden geçtiğini ifade etmiştir. Emir Şekip Arslan verdiği beyanatında Arapların Türk idaresini istediklerini belirtmiştir. Beyanatı şu şekildedir: "Arapların ekseriyeti azamiyesi Türk idaresini istediklerini, kendisinin de buna taraftar olduğunu, ahalinin kendisine müracaatla Suriyelilerin hukukunu talep için Cemiyet-i Akvama müracaat etmek üzere Cenevre'de akd edilecek içtimaa iştirakını rica ettiklerini söylemiş ve bu teklifi kabul ederek "Kaleme aldığı lahiyalarda Türklerle beraber yaşamak hususundaki Arap milletinin arzusunu izhar etmiştim" demiştir. Fransızların Suriye'yi işgal altında tutmalarına dair gazeteye bu işgalin kalıcı olamayacağını ve Fransızların gitmek zorunda kalacağını ifade etmiştir: "Fransızların Suriye'yi muhafaza edemeyeceklerini, Suriye'de şimdiye kadar bu kadar derin bir asayişsizlik görülmemiş olduğunu ifade etmiştir." Haberde yer alan diğer bir içerik ise Ahenk gazetesine Suriye'den gelen mektuba dairdir. Mektupta Halep civarındaki mücahitlerin Fransızlara karşı gerçekleştirdikleri saldırılar yer almaktadır:

"Genç Suriyelilerden müteşekkil mücahitler kafilesi Halep'in şark ve şimal-i şarkiyesinde faaliyetlerini artırdıklarından Fransız kuvvetleri korkularından artık şehir haricine çıkamıyorlar. Mücahidin her gün baskın yapmakta devam ediyorlar. Fransızlar, verdikleri azim telefata mukabil şimdiye kadar 23 mücahidi esir alabilmişlerdir."

Mektubun ikinci kısmında ise ilginç bir şayia yer almıştır. Bu şayia Halep'in Musul şehrinin ardından Türkiye'ye bağlanacağına dairdir. Bu haber Şam'da büyük bir coşkuyla karşılanmıştır: "Teşrin-i Evvelin dokuzuncu günüde Musul'a, mukabil Halep'in bize terk edileceği şayiası zuhur etmiş ve Şam Müslümanları adeta şehr-i ayin yapmışlardır. Şam ve Halep'te Fransızlar ve Hristiyanlar müthiş korku içindedirler." Görüldüğü üzere verilen habere göre Halep şehrinin Türk yönetimine katılacağına dair haberlerin Şam'da büyük bir sevinçle karşılandığı iddia edilmektedir. Bu tarz haberlerde dikkat edilmesi gereken bir diğer husus ise Türkiye'de yayınlanmakta olan gazetelerin bu tarz konuları sık sık okuyucusuna sunmasıdır. Bu durum dahi basında "Araplar bizi arkamızdan vurdu" iddiasının geneli kapsamadığını göstermektedir. Herhalde böyle bir düşünce zihinlere kazıımış olsa Arap ülkelerinde olup bitenler Türk basınının gündeminde

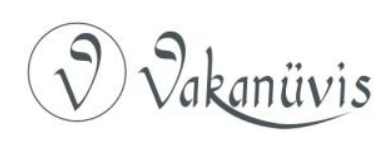


yer tutmazdı. Haberde değinilen bir başka husus ise Halep'te bir Türk kadının yaptığı konuşmadır: “Bir Türk hanımı Halep'te müessir bir nutuk irad ve İslamları düşman esaretinden kurtulmak için mücahedeye davet etmiştir. Ahval gayet naziktir." Ahalinin Türk idaresini istediği bildirilmekte ve Suriye'de ki durum şu cümlelerle özetlenmektedir: "Vaziyet, patlamaya hazır bombaya benziyor."

Görüldüğü üzere, 1923-1927 yılları arasında, Suriye halkının henüz milliyetçiliğin yıkıcı etkisi altında girmemiş ve Fransa tam manasıyla ülkeye hakim olamamıştır. Ulus-devlet sürecindeki iddiaların aksine Suriye halkının Türk yönetimini "baskıcı işgal"76 dönemi olarak tanımlamadıkları görülmektedir. Bilhassa Suriye halkının Türkiye'ye olan bağılığını gösteren haberlerin Hakimiyet-i Milliye gazetesinde yer alması, Cumhuriyetin ilk yıllarında Araplara karşı Türk basınında henüz bir kırılma yaşanmadığını göstermektedir.

\section{Sonuç}

Suriye halkının Türkiye'ye dair bakış açısını görme fırsatını sunan, Türk basınındaki haberler oldukça önemlidir. Muhakkak ki Türk basınına yansıyan haberler, Arap-Türk ilişkileri için tek başına yeterli bir ölçü değildir. Ancak dönemin Arap halkının bakış açısının Türk basının gözünden sunulmuş olması bizlere göz ardı edilemeyecek bir veri sunmaktadır. Söz konusu olan haberler birkaç açıdan değerlendirilmelidir. Bu değerlendirmenin ilki Türk basınının, Araplara karşı olumlu bir bakış açısına sahip olduğunu göstermesidir. Türk basınının Suriye'deki gelişmelere ilgisiz kalmamış ve Şam, Halep gibi şehirlerde yaşanan gelişmeleri gazete sütunlarına yansıtmıştır. Ayrıca haberlerde Suriye ve Suriye halkına karşı olumsuz bir izlenim görülmemektedir. Oysa Şerif Hüseyin'in I. Dünya Savaşı sırasında gerçekleştirdiği isyanın üzerinden uzun bir süre geçmemiştir. İncelenen gazeteler, Şerif Hüseyin'in gerçekleştirmiş olduğu isyanı Suriye Arap halkına mal eden bir ifade kullanmamıştır. İkinci değerlendirme ise verilen haberlerin Suriye ahalisinin olumlu bakış açısını göstermesidir. Verilerin gösterdiği tablo da Suriye halkının geneli Osmanlı́yı Arapları

\footnotetext{
${ }^{75}$ Suriye Ahvali, Hakimiyet-i Milliye, 28 Ekim 1923.

${ }^{76}$ Jane Hathaway, Osmanlı Hakimiyetinde Arap Toprakları, 1. Baskı, İstanbul, 2016, s.5.
}

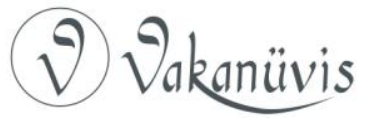


baskı altında tutan bir yönetim olarak görmemekte ve bu yönetime karşı özlem duymaktadır.

Yine Suriye ahalisinin Türkiye'nin yöneticilerine karşı saygı duydukları ve Milli Mücadele'de gerçekleşen zaferleri benimsedikleri görülmüştür. Bu sebepledir ki Suriye şehirlerinin Türkiye'ye bağlanma arzuları basınımızda yer bulmuştur. Hatta Halep şehrinin Türkiye'ye bağlanacağı söylentileri dahi Şam'da sevinçle karşılanmıştır. Bilhassa Milli Mücadele'nin liderlerinin saygı ve sevgiyle anılması Fransız yönetimini tedirgin etmiştir. Diğer önemli husus ise Suriye'de Fransız yönetimine karşı olan direniştir. Haberler bize şunu göstermiştir ki, Suriye halkının geneli Fransız yönetimine karşı teslimiyetçi bir tavır göstermemiştir. Bu husus önem arz etmektedir. Çünkü Türkiye kamuoyunda yer alan algılardan biri de Milli Mücadele yıllarında, Anadolu halkı büyük bir direniş gösterirken Suriye bölgesi gibi Arap diyarlarında işgalci yönetimlere karşı bir direniş var olmadığı düşüncesidir. Oysa Türk basınında yer alan haberlerde Suriye'de Fransız yönetimine karşı bir direnişin var olduğu görülmektedir. Suriye direnişinin Milli Mücadele benzeri bir harekat tarzını benimsedikleri dönemin Türk basınına yansımıştır. Söz konusu husus akademik çalışmalarda da yer almıştır. Belki de bu mücadelede Suriye halkının en büyük eksikliği, Anadolu'daki mücadelenin aksine Osmanlı ordusunun büyük kumandalarına ve Osmanlı ordusunun iskelet yapısına sahip olmamasıdır. Suriye direnişinin Milli Mücadele hareketini örnek aldığına dair var olan haberler ise Suriye halkının, Milli Mücadele hareketine olan ilgisini de göstermektedir.

Arap milliyetçiliğine dair ilk düşüncelerin ortaya çıktığı Suriye'ye ait elde ettiğimiz bu tablo oldukça ilgi çekici bulunmaktadır. Elde ettiğimiz sonuçlar bize şunu göstermiştir ki, Türk-Arap ilişkileri tarihini tek bir aktör üzerinden okumak bizi yanlış sonuçlara götürecektir. Dönemin Arap halkının bakış açısını yansıtacak olan çalışmalara ihtiyaç vardır. Yine son dönem Türk-Arap ilişkilerinde bir travma oluşturan Şerif Hüseyin'in gerçekleştirmiş olduğu isyanın tüm Araplara mal edilemeyeceği görülmüştür.

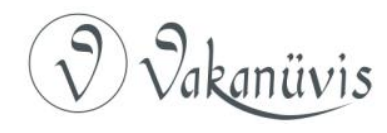




\section{Kaynakça}

Arı, Tayyar, Orta Doğu, Bursa 2008.

Arslan, Emir Şekip, Şehit Suriye, İstanbul 2014.

Antonious, George, The Arab Awakening, London 1945.

Cleveland, William, Modern Ortadoğu Tarihi, İstanbul 2008.

Cleveland, William, Batı́ya Karşı İslam, ìstanbul 2017.

Çiçek, Talha, Şerif Hüseyin isyanının Türk ve Arap kimlik inşa Süreçlerindeki Etkisinin Analizi, Yayınlanmamış Yüksek Lisans Tezi, Sakarya 2007.

Çiçek, Talha, "Erken Cumhuriyet Dönemi Ders kitapları Çerçevesinde Türk Ulus Kimliği İnşası ve Arap inaneti", Divan Disiplinler Arası Çalışmalar Dergisi, Cilt.17, Sayı.32, 2012.

Dawn, Ernest, Osmanlıclıktan Arapçılığa, İstanbul 1998.

Emecen, Feridun, Osmanlı Imparatorluğunun Kuruluş ve Yükseliş Tarihi, İstanbul 2016.

Erden, Ali Fuat, Birinci Dünya Savaşı'nda Suriye Hatıraları, (haz. Alpay Kabacalı) İstanbul 2006.

Fromkin, David, Barışa Son Veren Barış, ìstanbul 2016.

Georgeon, François, Osmanlı-Türk Modernleşmesi, i̇stanbul 2016.

Hathaway, Jane, Osmanlı Hakimiyetinde Arap Toprakları, İstanbul 2016.

Karpat, Kemal, Ortadoğu'da Millet, Milliyet, Milliyetçilik, ìstanbul 2011.

Koloğlu, Orhan, Fizan Korkusundan Libya Mücahitliğine, İstanbul 2008.

Kurşun, Zekeriya, Türk-Arap İlişkileri, ìstanbul 1992.

Selvi, Haluk, "Ingiltere'nin Musul Politikası Karşısından Osmanlı Devleti ve Bölge Aşiretleri (1918-1920)", Belleten, Cilt: LXXIV-Sayı: 271-Yıl: 2010 Aralık.

Selvi, Haluk, Milli Mücadelede ilk işgaller ilk Direnişler, İstanbul 2014.

Selvi, Haluk, Sorularla Türkiye Cumhuriyeti Tarihi, İstanbul 2017.

Umar, Ömer Osman, Suriye, Ankara 2004.

Tansel, Selahattin, Mondros'tan Mudanya'ya Kadar, Ankara 1978.

TBMM GCZ, 24 Nisan 1336 (1920), Ankara: İş Bankası Kültür Yayınları, 1985, C.1, Devre 1, İçtima 1, İn'ikat 2, 24.4.1336

\section{Gazeteler}

Hakimiyet-i Milliye Gazetesi

Suriye'de Vaziyet, Hakimiyet-i Milliye, 22 Şubat 1923

Suriye Haberleri, Hakimiyet-i Milliye, 17 Teşrin-i Sani 1923

Suriye Haberleri, Hakimiyet-i Milliye, 23 Eylül 1923
Şam'da bir Tezahür, Hakimiyet-i Milliye, 23 Eylül 1923

Suriye Mektubu, Hakimiyet-i Milliye, 1 Teşrin-i Evvel 1923

Suriye Üzerinde ki Gizli Emeller, Hakimiyet-i Milliye, 4 Teşrin-i Evvel 1923

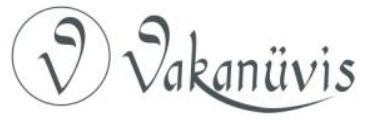


Suriye Ve Fransa, Hakimiyet-i Milliye, 16 Ağustos 1923

Suriye Haberleri, Hakimiyet-i Milliye, 26 Eylül 1923

Suriye Havadisleri, Hakimiyet-i Milliye, 11 Temmuz 1923

Suriye'de Karışıklık, Hakimiyet-i Milliye, 8 Teşrin-i Evvel 1925

Suriye'de Fransa, Hakimiyet-i Milliye, 8 Teşrin-i Evvel 1925

Suriyeliler Cumhuriyet Ilan Ediyorlar, Hakimiyet-i Milliye, 16 Teşrin-i Sani 1925

Suriye Hakkında, Hakimiyet-i Milliye, 17 Teşrin-i Sani 1925

Suriye Hakkında, Hakimiyet-i Milliye, 15 Kanunu Evvel 1925

Şam Kıyamı, Hakimiyet-i Milliye, 22 Teşrin-i Evvel 1925

Suriye Vukuat, Hakimiyet-i Milliye, 28 Teşrin-i Evvel 1925

Suriye Ahvali, Hakimiyet-i Milliye, 27 Teşrin-i Evvel 1923

Suriye'de Fransızlar, Hakimiyet-i Milliye, 30 Temmuz 1926

Suriye Fevkalade Komiserinin Beyanatı, Hakimiyet-i Milliye, 29 Ağustos 1926

Suriye'de Muharebeler Devam Ediyor, Hakimiyet-i Milliye, 26 Temmuz 1926

Suriye'de Fransızlarla Yerlilerle Arasında, Hakimiyet-i Milliye, 16 Ağustos 1926

Suriye'de Fransızlarla Yerlilerle Arasında, Hakimiyet-i Milliye, 13 Eylül 1926

Suriye'deki Kabine, Hakimiyet-i Milliye, 6 Temmuz 1926

Suriye'de Vaziyet, Hakimiyet-i Milliye, 6 Mart 1926
Suriye'de Şiddetli Muharebeler Oluyor, Hakimiyet-i Milliye, 3 Ağustos 1926

Suriye Nazırı, Hakimiyet-i Milliye, 3 Temmuz 1926

Suriye'de Fransızlar, Hakimiyet-i Milliye, 3 Ağustos 1926

Suriye'de Yerlilerle Fransızlar Arasında, Hakimiyet-i Milliye, 21 Mayıs 1927

Muharebeler Devam Ediyor, Hakimiyet-i Milliye, 2 Ağustos 1926

Şam Ahvali Hakkında Tafsilat, Hakimiyet-i Milliye, 29 Teşrin-i Evvel 1925

Şam İhata Ediliyormuş, Hakimiyeti Milliye, 27 Temmuz 1926

Şam'daki Teşebbüs, Hakimiyet-i Milliye, 11 Eylül 1926

\section{İkdam Gazetesi}

Suriye İhtilalcilerin Programları, İkdam, 13 Eylül 1926

Suriye Vakayı, İkdam, 4 Haziran 1926

Suriye İhtilali, İkdam, 24 Temmuz 1927

Lozan'da Suriye Heyet-i Murahhasının Beyanatı, İkdam, 5 Temmuz 1923

Suriye Havadisi, İkdam, 13 Ocak 1926

Suriye İhtilalcilerin Programları, İkdam, 13 Eylül 1926

Suriye'de İsyancıların Mühim Mutalebatı, İkdam, 19 Haziran 1926

Suriye Havadisi, İkdam, 13 Ocak 1926 
Suriye Muharebeleri, İkdam, 15 Mayıs 1926

Suriye Haberleri, ikdam, 25 Ocak 1926

\section{Vakit Gazetesi}

Dürzi İsyanı, Vakit, 20 Ağustos 1925

Şam Tehlikede mi?, Vakit 28 Ağustos 1925

Dürzi İsyanı Hangi Safhada Bulunuyor, Vakit, 31 Ağustos 1925 Fransızlar Zulüm Ektiler, İsyan Biçtiler, Vakit, 3 Eylül 1925
Düriler Suvey'e Mevkine Girdiler, Vakit, 17 Eylül 1925

Fransızlar ve Dürziler, Vakit, 20 Eylül 1925

Fransız Ordusu, Vakit, 24 Eylül 1925

Fransiz Ordusu Ricat Etti mi?, Vakit, 21 Ekim 1925

Suriye'de Neler Oluyor, Vakit, 14 Mart 1926

Şam Viran Bir Köy Gibidir, Vakit, 15

Mart

1926 